\title{
The Effects of Training to the Employee Performance and Development: A Study of Fareast Islami Life Insurance Company Limited, Bangladesh
}

\author{
Md. Shahinur Hassan \\ Commonwealth Executive MBA (CEMBA) Programme \\ Bangladesh Open University, Bangladesh \\ E-mail: shahinurtgr@yahoo.com \\ Md. Mizanuzzaman \\ Deputy Controller of Examinations \\ Z. H. Sikder University of Science and Technology, Bangladesh \\ E-mail: mizanuzzaman@gmail.com \\ K. M. Anwarul Islam \\ Associate Professor \\ Department of Business Administration \\ The Millennium University, Dhaka, Bangladesh \\ $\mathrm{PhD}$ Candidate \\ University of Selangor, Malaysia \\ E-mail: ai4I9bankingdu@gmail.com
}

Received: June 25, 2020

Accepted: August 05, 2020

Online Published: September 29, 2020

doi: I0.4628I/ijbmf.v4i2.785

URL: https://doi.org/I0.4628I/ijbmf.v4i2.785

\begin{abstract}
Fostering more efficient capital allocation; encouraging loss mitigation; enabling risk to be managed more efficiently; helping mobilized savings; facilitating trade and commerce; substituting for and complementing government security programs and promoting financial stability insurance company plays a vital role to a country's economy. Despite prolonged political instability, poor infrastructure, endemic corruption, insufficient power supplies, and slow implementation of economic reforms Bangladesh's economy has grown by approximately 6 percent annually for two decades. In this case, the insurance companies of Bangladesh have been keeping a significant role for a long since. Considering the enhancement of the development of insurance sectors, different institutes and academics have been established. But those are inadequate for the fulfillment of developing this industry and manpower also. So, regarding this context, I select the matter of The Effects of Training \& Development of Performance: A Case Study of Fareast Islamic Life Insurance Ltd. This study is conducted to Fareast Islamic Life Insurance Head Office and its five branch offices. Identification of the improvement of manpower and their occupational development and how they can contribute to their organization is the main issue of this study.
\end{abstract}

Keywords: Effects, Training, Development, Employee Performance, Islami Life Insurance.

\section{Introduction}

There is a significant role to develop for the further advancement of a country's economy by its financial sector (Ahmad and Malik, 2009). The financial sector of Bangladesh comprises the credit market, money market, Islamic and non-Islamic insurance companies, several financial institutions, capital markets, and microfinance (Khan, 20I4). The Ministry of Commerce in Bangladesh governs the entire insurance sector as well as Islamic and non-Islamic insurance companies (Chowdhury, 20I4). Even though the origins of insurance can become into the light from the earliest period, so, it is not easy to envisage when insurance was commenced in the world evolution (Rispler-Chaim, I99I). In 1938, the first Insurance Act was enacted in the Indo-Pak subcontinent (Samarth, 2003). At present, the insurance companies of Bangladesh are governed on the Insurance Act 2010 (Insurance Development \& Regulatory Authority Bangladesh, 2013). Some insurance companies were launched from 1947 to 1970, while Bangladesh was identified as East Pakistan (Rahman, 2013). More than 47 insurance companies together with local 
and international were in service in East Pakistan till 1972 and the whole business was run as the private companies there. On the other hand, all insurance companies, both life and general except the overseas insurance company, were publicly owned by the Presidential Order titled the Bangladesh Insurance Order, 1972 on March 26, 1972 (Ali, 2000). During the pre-liberation period of Bangladesh, the insurance sector was governed by the authority of West Pakistan and then there was a little bit of development in this sector (Rahman, 2013). There was a very lack of opportunity to train up human resources. For meeting the improvement of the insurance sector, the Government of the People's Republic of Bangladesh established the Bangladesh Insurance Academy in November 1973 (Chaudhrui, 2008). The academy provides proficiency certificates and diplomas, and also conducts research on the insurance industry, also offers in-service training for officers and employees of public and private sector insurance organizations, publishes research papers on insurance, recognize close associates with local and overseas academic institutions, collaborates combined courses, and invites students and trainees from abroad (Bangladesh Insurance Association, 2016).

Training and development is the apprehensive field with managerial activity aimed at improving the performance of individuals and groups in consideration to the field of human resource management, in an organizational setting. It has been considered in different ways like employee development, human resource development, and learning and development. This study aimed at an exploratory way to the effect of training and development on employee performance with a case study of Fareast Islamic Life Insurance. Literature review of this study, derived from another scholars involvement to the subject matter to this research were commonly discussed on the indication of training, methods of training, reimbursement of training, employee activities, assessment of training, an association between training and development, and employee performance which led to gap analysis as at the ending of the chapter. The study had been adopted with a case study approach where data were collected across a population through a sampling of I50 employees at the different sectors including the head office and at least five branch offices of Fareast Islamic Life Insurance Company. The sample had been included managers, support analysts and customer experienced executives. Primary data were collected by using both structured and unstructured questions across the strata and secondary data were gathered from various sources such as the Company Annual Reports, Employee Booklet, and Employee Performance Reports. Responses by the respondents have been analyzed using both descriptive and graphical techniques.

Some major remarkable findings have been included here. It is found that $95.2 \%$ of the respondents replied that it is very necessary of training program to improve their personal skill and development of the company, $62.66 \%$ respondents attended only one training program, $42.85 \%$ of the respondents said the trainers followed Classroom or Instructor-Led Training and $28.57 \%$ of them applied Interactive Training Techniques, $50 \%$ of the respondents said the duration of the training program conducted in I to 2 days and $19.8 \%$ received $4-7$ days training, $40 \%$ of the respondents said that the training program help to improve their Teamwork skill $32 \%$ said Technical and other skills, $86.66 \%$ of the respondents said the trainer is experienced in the session and some of the respondents said they do not get correct information, $30 \%$ of the respondents said the trainer is well prepared for the training program, $40 \%$ of the respondents said the communication skill improved, I6\% said their technical skill improved and another $32 \%$ said their teamwork skill improved.

The major recommended issues by the respondents are training must be informative; training classroom environment must be quiet; to involve capable trainers and using proper training instruments, tools, and techniques. It will be observed that training and development has a positive impact on both motivations of employees as well as performance. The study recommends that the importance of training to the staff should be considered based on in general companionship objectives of the company. In addition to the targets of the company should be determined what type of training programs are to be conducted for staff.

\section{I.I The rationale of the Study}

Different issues like to find out the factors affecting the performance of the employee, to analyze the effect of the training program, to study the training and development programs, to evaluate the effectiveness of the training and development programs offered for Bank employees in our country were discussed and analyzed. Besides those to seek suggestions from the employees on improving the present system, to analyze the risk and profitability of Fareast Islami Life Insurance Company Limited were discussed but there is no significant analysis on employee development and the development of the insurance company is found here. Considering these issues, the analysis of effective training providing to the employees and its impacts (negative and positive) to the insurance sector in Bangladesh should be kept a significant role. In this regard, this issue has been considered to discuss here.

\section{I.2 Objectives of the Research}

- To identify the existing Training and Development trends \& programs in Fareast Islamic Life Insurance Company Limited,

- To find out the relationship between Training \& Development and employees' performance,

- To ascertain satisfaction levels of employees on improving the present system; and 
- To evaluate the effectiveness of the training and development programs.

- To seek the problems and solutions faced during the training session.

\section{I.3 Scope of the Study}

This study will cover the following areas

Area: Head office along with five sub or local office has been selected to conduct this study

Sample Size: Targeted respondents are initially selected, I40 employees. They are

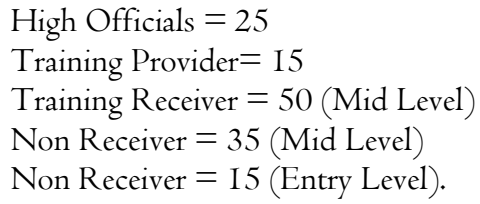

\section{I.4 Limitation of the Study}

Human Resources Development is an important part of a company's development. Without the advancement of this process, the company's progress, prospects, strength, and improvement is beyond to measure. Training of the employees is very essential for the development of the company. The previous works which have been reviewed were done in Bangladesh, The Effect of Training \& Development on Employee Performance in the area of Insurance has not found yet. Several articles have been read to identify the weakness on the side of Training \& Development on Employee Performance and the development of the company. Most of the articles and journals were written mainly depending on the banking sector. Not only Bangladesh but also all over the world, insurance companies have a vital role to develop the economy of a country. So, in consideration of the evaluation indicators of a company, Human Resources Development is one of them. Fareast Islamic life Insurance Company Limited is a leading and dominating insurance company in our country. So, to train employees and officers of this company regarding Shariah-compliant Takaful practices and all systems related to Shariah is much needed. Thus, this constitutes a knowledge gap that the present study seeks to fill the purpose of the study therefore, it is to establish the relationship between training and development, and employee performance in the insurance sector especially Shariah-compliant Takaful practices and to ascertain satisfaction levels of employees on improving the present system is identified to understand.

\section{Literature Review}

Numerous published and unpublished articles were identified for the assessment of the impacts of training on the employees and organizations in our country and other countries. A list of articles referred to in developing this thesis paper is provided in this section. R. Khan, F. Khan, \& M. Khan (20II) tried to focus of their study is to understand the effect of Training and Development, On the Job Training, Training Design, and Delivery style on Organizational performance. Ramakrishna, Kumar, Girdhar, and Krishnudu (2012) took an attempt to highlight the factors which, if implemented, may lead to a substantial transformation of banks to compete in an environment of risks and uncertainty in India. Rahman (20I3) endeavored in his study to examine the efficiency in both the life insurance and life Takaful industry of Bangladesh. Jehanzeb and Ahmed Bashir (2013) inspect the structure and elements of employee training and development program and later the study present what are the positive outcomes for employees and organizations. Tried to find out the factors affecting the performance of the employee and analysis the effect of the training program Khan, Rahman, Yusoff, and Nor (2016) explain the history, current problems, and future possibilities of Islamic insurance (takaful) in Bangladesh. Sarwar (2016) aims to examine the experience, challenges, and key drives for the growth of the latest progress of the Takaful industry in Bangladesh. Ferdawshi (2016) tries to show overall HR practices, such as recruitment and selection, training and development, performance management, staffing, etc. of the M\&J group. It also mentions how the company is developing strategic human resource practices along with their business strategies. Khan (20I4) tries to analyze the risk and profitability of Fareast Islami Life Insurance Company Limited. Amadi (20I4) recommends that training needs at Safaricom should be considered based on overall company objectives. Imran and Tanveer (2015) concluded up with Training \& Development positively impacting the employees' performance in the banks of Pakistan. Vyas and Mistry (2015) are to examine the effectiveness of Training in the cement industry is a critical aspect of the development of knowledge of the workforce in India. Raja and Kumar (2016) and Islam and Zaman (2013) evaluate the effectiveness of training and development programs in Ashok Leyland Ltd. in India.

Khan et al. (2016) Job analysis - manpower planning - at the start of the business and as ongoing process performance appraisal - standards, methods, and errors were observed. From the early stage of the 2Ist century, we found that a remarkable flow surrounded by the businesses to draw and keep hold of the endowment. This is very much exhibited due to globalization, technological development (Allen, 2010), and in particular be augmented contests within the market economy and 
international market (Qayyum, Sharif, Ahmad, Khan, \& Rehman, 2012; Kumpikaite \& Sakalas, 20II). The demands of the human resources are provided with an uninterrupted knowledge acquisition feeling to keep themselves on the pathway with the organizational goals. In consideration of Spender (2002) employees must gather a variety of skills and broad knowledge in terms of the different individual as well as proficient attributes. Of course, performance should be the decisive goal of any business's efforts which leads towards the attainment of market guidance and capturing of invincible aptitude. Both of these are vital for the organizations and are part of the institutional calculated operation (Mwita, 2000). To acquire training was once deliberation of as a further attempt to do extremely well individually and carry out to the mark in one's job but now it has become an issue of indispensable need to be skilled to find out the alteration and adjust to the advancements in work practices (Garner, 2012). In addition to it is an indubitable fact that in response to the shifting job practices if workforces are not given support with the likelihood to increase their specialized experiences then this may guide them to backdated skill and skill of obsolescence. The skill obsolescence was defined by Greenhaus, Callanan, \& Godshalk (2000) to be the nonappearance of sophisticated knowledge and highly developed proficiency requisite to carry out executive tasks. Such circumstances have led organizations, despite their dimension and capacity of operations, to highlight capability-based hiring and set demanding job tasks. Competency-based recruiting is not all that is done but also human resources are qualified and developed to be practical and influential through in particular planned training and development $(T \& D)$ programs. These $T \& D$ programs in cooperation with offering basic skill improvement help in advance to highly developed job-related acquaintance to keep away from ability obsolescence too. Noe (2008) recommends that it is an organization's administration accountability to make possible the workforce throughout training \& development to hang about proficient in their occupation. Sharma and KU (2013) tried to identify training, to be aware of the need and justification of training to be grateful for the benefits of guidance to the employees and the institute, and to know the role of the trainers in the quickly shifting financial system.

\section{Research Methodology}

The study is descriptive. Because it describes opinion, the effectiveness of training and development. Non-probability sampling has been used in this study. Under this non-probability sampling, convenience sampling was chosen. The data was collected through a structured questionnaire. Further, the research is designed to employ simple statistical tools.

\section{I Research Design}

The focus of the study is to understand the present performance appraisal system in Fareast Islami Life Insurance Company Ltd. Find out the weaknesses of the practices and suggest measures to overcome those challenges as per the opinion by the respondent. It was, therefore, decided to use the explorative design, which befits the pattern of investigation. The study also understood and fleshed out to explain the job analyses and other basic performance appraisal practices of Fareast Islami Life Insurance Company Ltd. The current practices of developing and managing human resources were explored and a description of all these practices was analyzed through appropriate questionnaire and schedule, including the verbatim recording of the responses of the respondent.

\subsection{Sources of Data}

Primary Data: The primary data to be collected from the employees of the company, such as HR officers, In-charge of various departments, divisional in-charge, executives, and officers of the organization from the head office 'Fareast Tower' and other divisional and service center through physical and telephone interview by a structured questionnaire.

Secondary Data: The sources of secondary data are mainly collected from the company website, various published and unpublished documents, books, and some records. These data will be combined with desk research using different libraries and websites.

\subsection{Sample Selection}

The sample for the study was collected from different sources like; High Officials, Mid-level employees, Training Providers, and Entry Level Employees of the Head office, Divisional Office (Dhaka North \& South Zone) of Fareast Islami Life Insurance Company Limited. Initially, the target was fixed for 200 populations as the sample size of the different sectors of the company. But at last, it had been fixed in I40 populations.

\begin{tabular}{lc}
\hline \multicolumn{1}{c}{ Type of Employee } & Population \\
\hline High Officials & 25 \\
\hline Training Provider & I5 \\
\hline Training Receiver (Mid Level) & 50 \\
\hline Non Receiver (Mid Level) & 35 \\
\hline Non Receiver (Entry Level) & $\mathrm{I} 5$ \\
\hline \multicolumn{1}{c}{ Total } & $\mathrm{I} 40$ \\
\hline
\end{tabular}




\subsection{Data Collection}

Personal Interview: This is going to be the mode for collecting primary data. Line Managers of various departments, Assistant Managers, were interviewed.

Analysis Type: In this interview, mostly qualitative analysis was carried out with a mixture of structured and unstructured questionnaires. There were also a few quantitative analyses.

Sample Size: Senior officers of different branches were interviewed and a total of twenty officers were available.

Description: The analysis was carried out with the intent to know the perception of officers of senior officers of different branches on the research topic. A telephone interview also was conducted as it was required in a few cases.

\subsection{Data Analysis}

The data, after collecting from the selected respondents were analyzed and processed. The task of data processing consists of editing, coding, classification, and tabulation of collected data so that they will be amenable to analysis. To analyze the processed data, tables, graphs, and pie charts were used.

\section{Analyses, Results, and Discussion}

This section is the outcome of the analyzed data for the justification of this paper. This section relies on contains the analysis of primary data. The primary data have been collected through semi-structured questionnaires. The questionnaires have consisted of open-ended and closed questions. It was made up of two parts; Part A covering the general information about the respondents and the different pieces of training they have so far attended. Part B will seek to answer the research objective which was to find out the effect of training and development on employee performance. From November to December 2018, the data for this study were collected using a questionnaire and an interview schedule to the acknowledged I50 respondents within the three corporate offices of the Fareast Islami Insurance Ltd (Head Office, Divisional Office, Dhaka North, and South Zone Office). Questionnaires were distributed to the four types employees like High Officials, Training Provider, Trained and Non-trained employees of the organization out of which I40 questionnaires were completed and returned to the researcher. The response rate was therefore $97 \%$ of the sample and, $10 \%$ of the target population.

\section{I Demographics of the Respondents}

Gender, job position, education levels, and length of service are the main issues in this section. More than $66.4 \%$ of that survey is accountable for some form of training and development with personnel of an institution. The respondent summary consists of the members with a lot of gathering knowledge in this sector. Their experience and knowledge have been considered with their current employer in an average of 5 years of involvement at least 3 years in their current role. The maximum percentage of respondents is at present based on males (80\%) and the rest of the females (20\%).

Table I. Demographics: (Job Position \& Gender) of the Respondents

\begin{tabular}{|c|c|c|c|c|c|c|c|}
\hline Job Position & $\begin{array}{l}\text { Sample } \\
\text { Size }\end{array}$ & Percentage $\%$ & Male & Male\% & Female & Female\% & Ratio (M: FM) \\
\hline $\begin{array}{l}\text { High Officials (SVP, SEVP, and } \\
\text { DMD) }\end{array}$ & 25 & 17.86 & 20 & 80 & 05 & 20 & $4: 1$ \\
\hline Trainers of training & I5 & I0.7I & 12 & 80 & 03 & 20 & $4: 1$ \\
\hline Trained Employee (Mid-level) & 50 & $35.7 \mathrm{I}$ & 38 & 76 & 12 & 24 & $19: 6$ \\
\hline $\begin{array}{l}\text { Non-Trained (Mid Level \& Entry } \\
\text { Level) }\end{array}$ & 50 & $35.7 \mathrm{I}$ & 32 & 64 & 18 & 36 & $16: 9$ \\
\hline
\end{tabular}

Source: Field Survey, 2018

The table above indicates the type of officials who took part in that interview to prepare the paper. I40 officials who were directly given their opinion in terms of taking the interview and by inputting the questionnaire. Different types of officials like High Officials (SVP, SEVP, and DMD), Trainers of training, Trained Employee (Mid-level), and Non Trained (Mid Level \& Entry Level) were engaged in that session. Among the officials $75 \%$ were male and $25 \%$ were female and the ratio of them was 5I:I9. 


\subsection{Demographics of High Officials}

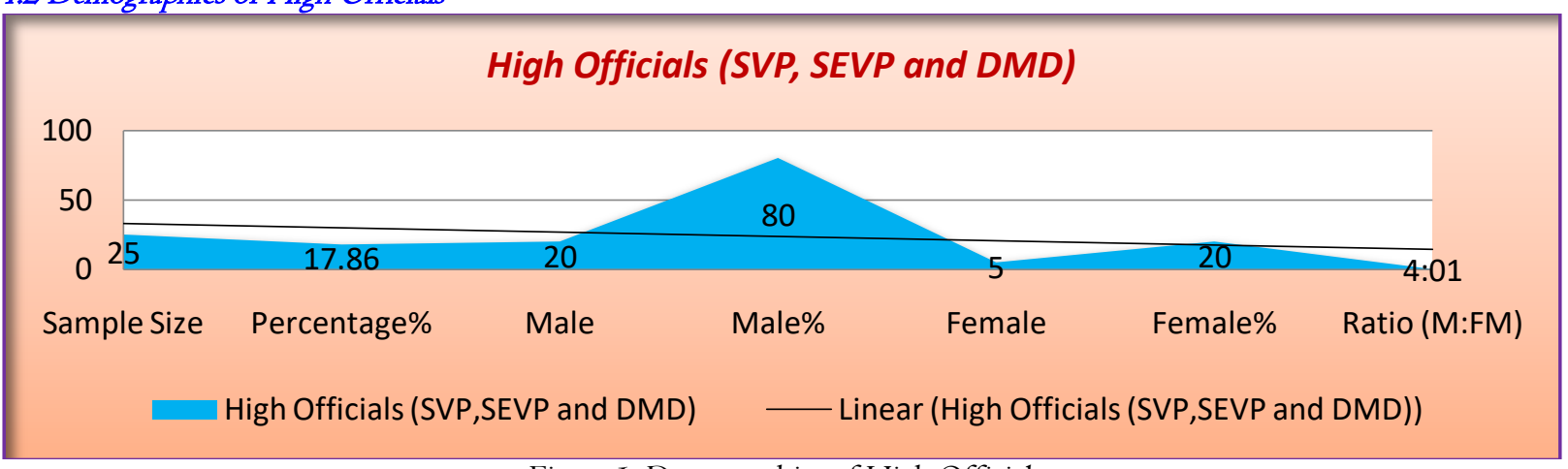

Figure I. Demographics of High Officials

Source: Field Survey, 2018

The chart above implies the expression of the segment of above table-I in which the high officials like Manager, Executive Vice President, and Vice President level were included sharing their opinions. 25 high officials, 17.86\% among the total sample size were given their opinion 20 people of them were male and 5 were female. And the ratio of males and females was $4: 1$.

\subsection{Demographics Trainers of Training}

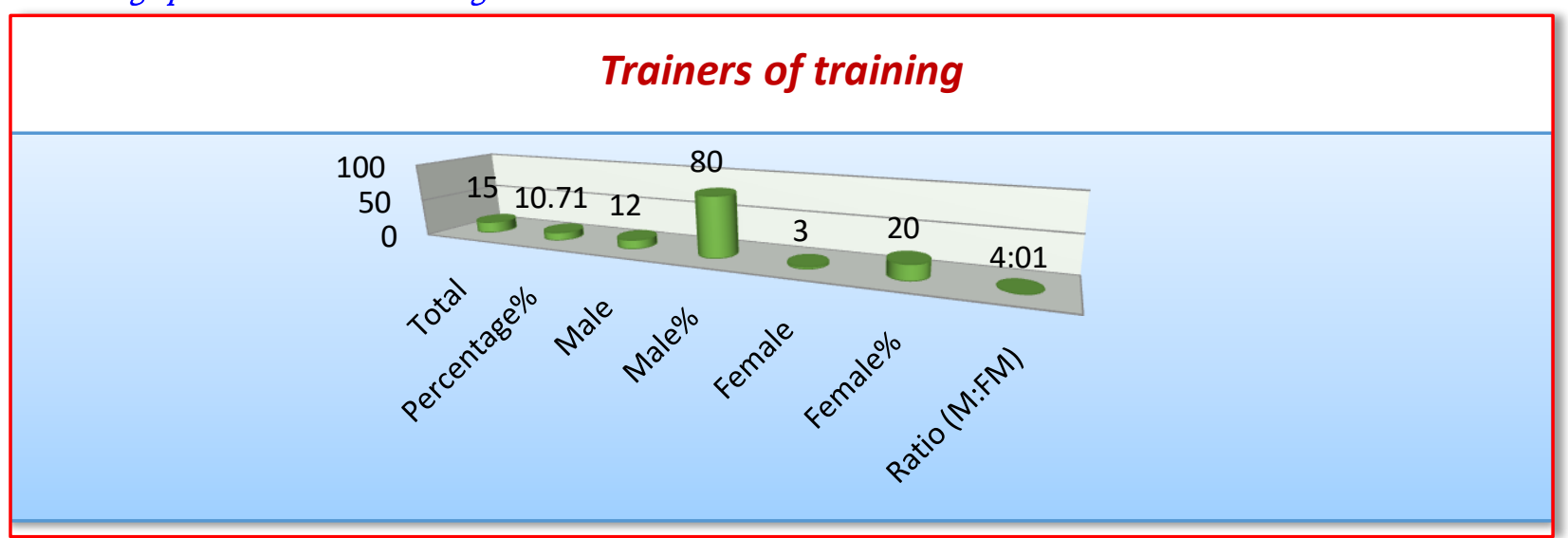

Figure 2. Demographics of Trainers of Training

Source: Field Survey, 2018

Trainers of training mean the training providers were also involved in my collection process of data. To know the tools and techniques of them which they apply in the training session are the main objectives for involving them. The figure refers to the demographics of the trainers of training. I4 master trainers were given their opinion and most of them were male. $10.7 \mathrm{I} \%$ of the total sample size is the training of trainers and the ratio of male and female is $4: \mathrm{I}$.

\subsection{Demographics of Trained Employee}

\section{Trained Employee (Mid level)}

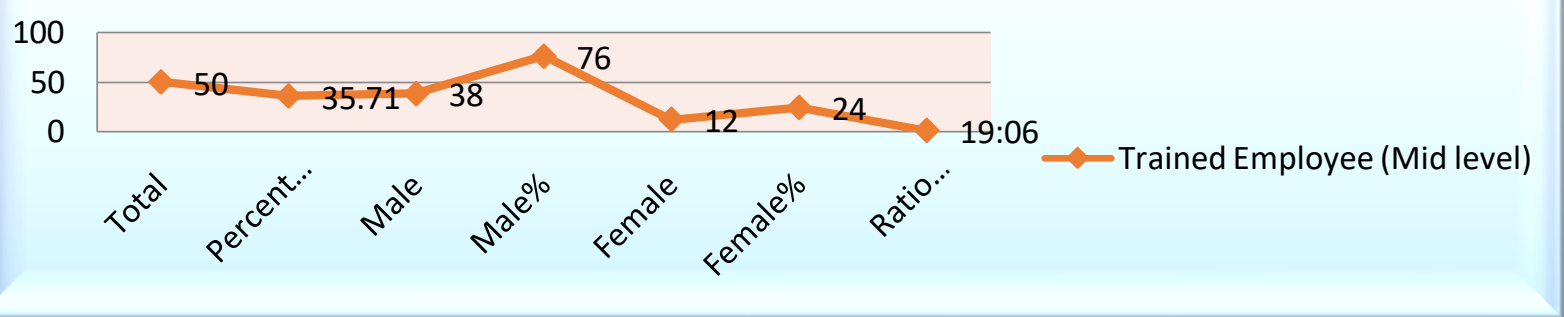

Figure 3. Demographics of Trained Employee

Source: Field Survey 2018 
To prepare this paper 50 persons of the mid-level employee were considered. Among the whole sample size, they were in $35.7 \mathrm{I} \%$ in which the majority of them e.g. 38 persons were male and 12 were female and the ratio of them is I9:6.

\subsection{Demographics of Non -Trained Employee}

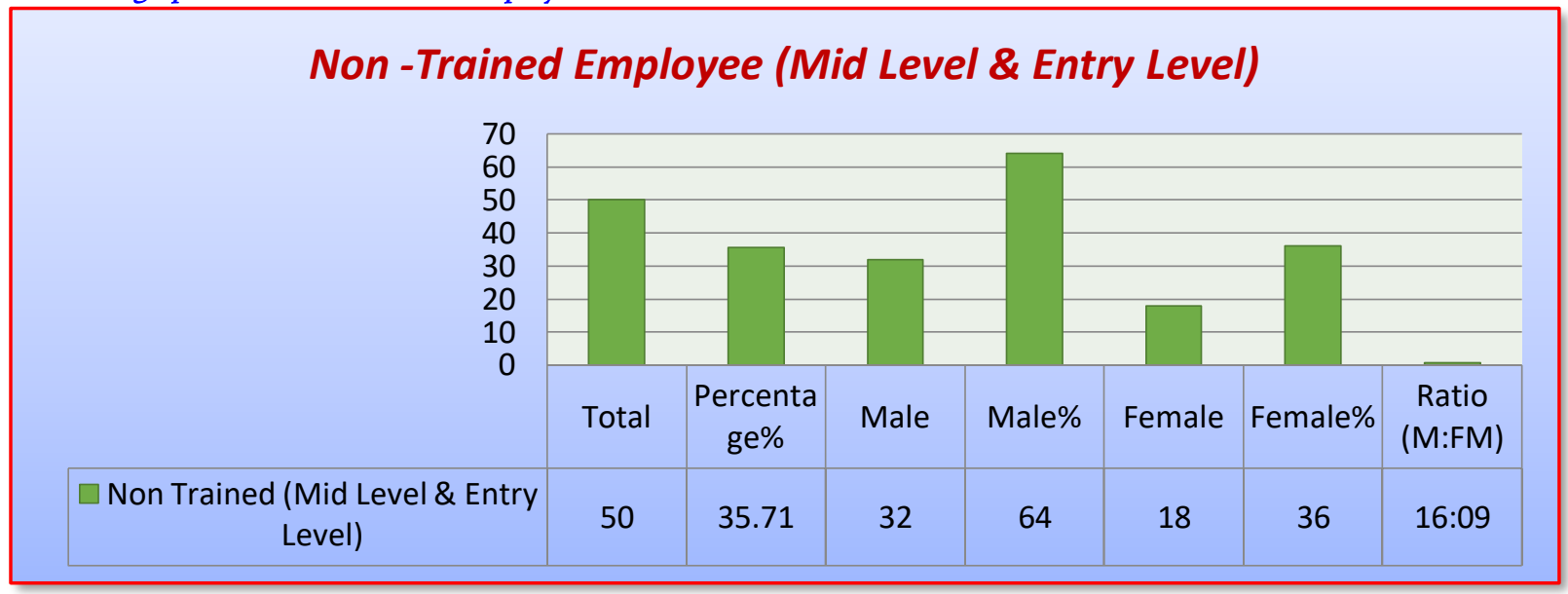

Figure 4. Demographics of Non -Trained Employee

Source: Field Survey, 2018

All the literature which are reviewed did not consider the non-trained people as their sample size. But in this paper, 50 non-trained employees who are involved in entry-level and mid-level were considered here. The main purpose of them to involve is to know about their opinion on the necessity of training for enhancing capacity and skill. In the figure above 35.7I\% of the total is a non-trained employee and the ratio of male and female is I6:9.

\subsection{Demographics (Education Level) of the Respondents}

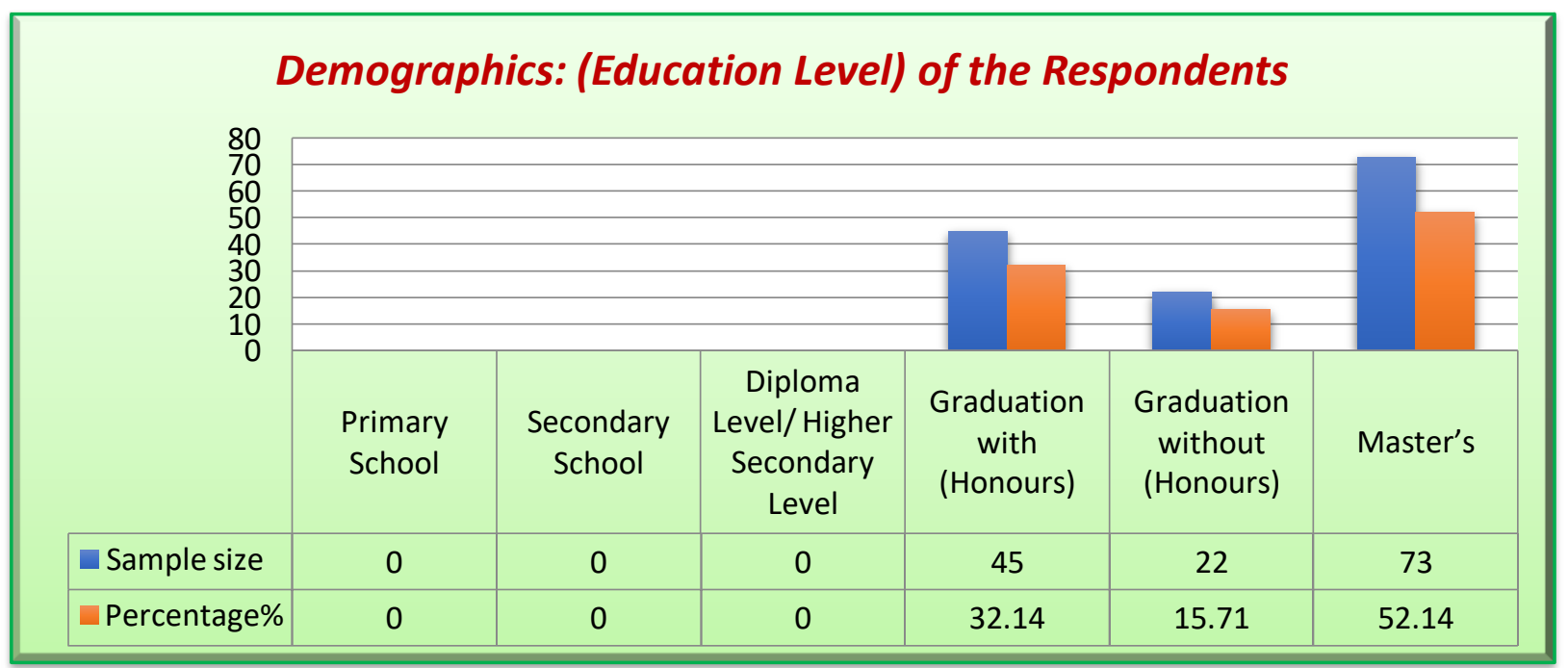

Figure 5. Demographics of Education level of Respondent

Source: Field Survey, 2018

Four types of selected people were engaged to express their opinion in this session. As they were from different levels so, understanding of their conception level of training and the relation with the development of their own and their organization, education level of them is a major factor I considered. Considering this matter the education level of them has to prefer this study. Six tires of educational steps e.g. (Primary School level, Secondary School level, Diploma Level/ Higher Secondary Level, Graduation level, and Master's level) had been considered as the indicators for that. The above figure indicates that the Master's level is the highest in the position of considering the educational level and its consistent percentage is $52.14 \%$. Another level is Graduation with (Honours) which implies 32.14\% and the below level of graduation indicates a percentage of $0 \%$. 


\subsection{Measure of Skill and Preparation of the Training Providers}

The skill and preparation of trainers is a vital issue for the trainees. Presentation skill and their applying tools and techniques influence the trainees. To understand their technique and gaily of arts the following issues have been considered in this part.

\subsection{Measuring Length of Experience of Training of Trainer}

Table 2. Measuring Length of Experience of Training of Trainer

\begin{tabular}{|c|c|c|}
\hline How many years are you involved as a trainer? & Sample Size & Percentage $\%$ \\
\hline I-2 Years & 02 & $\mathrm{I} 4.28$ \\
\hline Less than 5 Years & 04 & 28.57 \\
\hline Less than IO Years & 06 & 42.85 \\
\hline II- 20 Years & 02 & $\mathrm{I} 4.28$ \\
\hline Total & I4 & 100.00 \\
\hline
\end{tabular}

Source: Field Survey, 2018

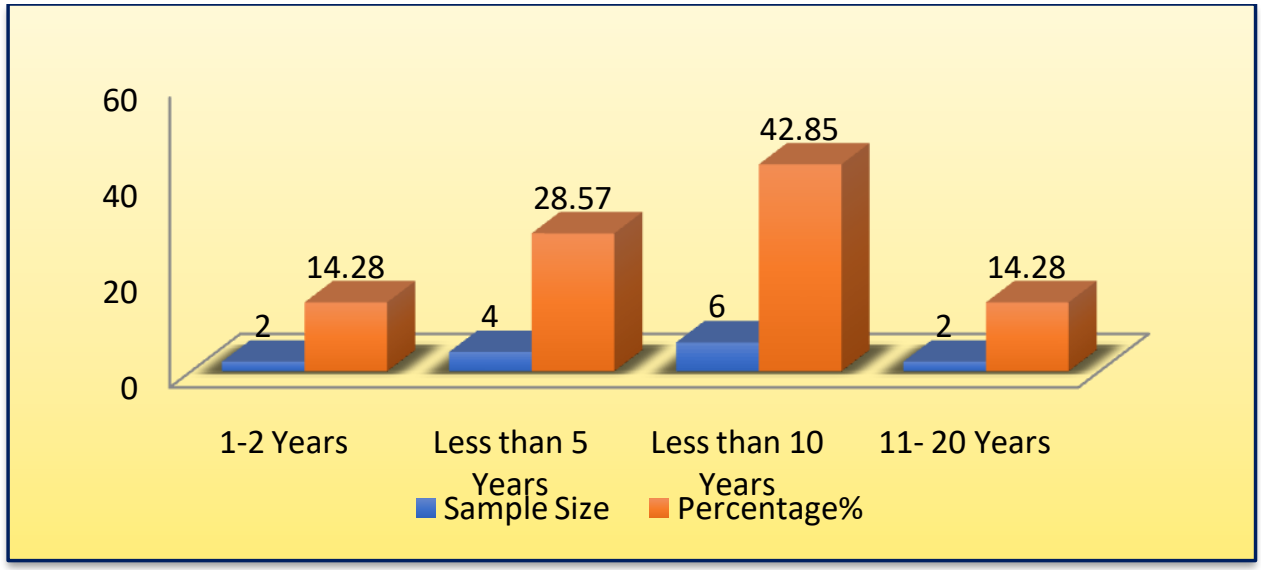

Figure 6. Length of Experience of Trainers of Training

In the figure above is the reflection of the Length of Experience of Training of Trainers. Four types of indicators have been considered to understand their length of experience. Among the four types of considering indicators 6 persons are at the level of fewer than 10 years of experience level and their belonging percentage is $42.85 \%$. Two types of experience levels are reflected as similar trends which are $14.28 \%$. By analyzing the figure most of the trainers are very much experienced here.

\subsubsection{Using Methods of Training}

Different types of training methods are used by trainers during the training session. The methods differ in the types of training. Among all the applying training methods five types of training methods like Classroom or Instructor-Led Training Method, Interactive Training Techniques, Hands-on Training Techniques, and E-Learning or Online-based Training Techniques were considered for the 14 respondents who provide training in the Fareast Islamic Life Insurance Ltd. According to their opinion, most of the trainers apply the Instructor-Led Training Method and Interactive Training Techniques.

Table 3. Using Methods of Training of Trainer

\begin{tabular}{lccc}
\hline Which methods do you apply in your providing training session? & Sample Size & Percentage\% \\
\hline Classroom or Instructor-Led Training & 06 & 42.85 \\
\hline Interactive Training Techniques & 04 & 28.57 \\
\hline Hands-on Training Techniques & 02 & 14.28 \\
\hline Computer-Based Training Techniques & 02 & 14.28 \\
\hline E-Learning or Online-based Training Techniques & 0 & 0 \\
\hline \multicolumn{1}{c}{ Total } & $\mathrm{I}$ & $\mathrm{I}$ & $\mathrm{I}$ \\
\hline
\end{tabular}

Source: Field Survey, 2018 


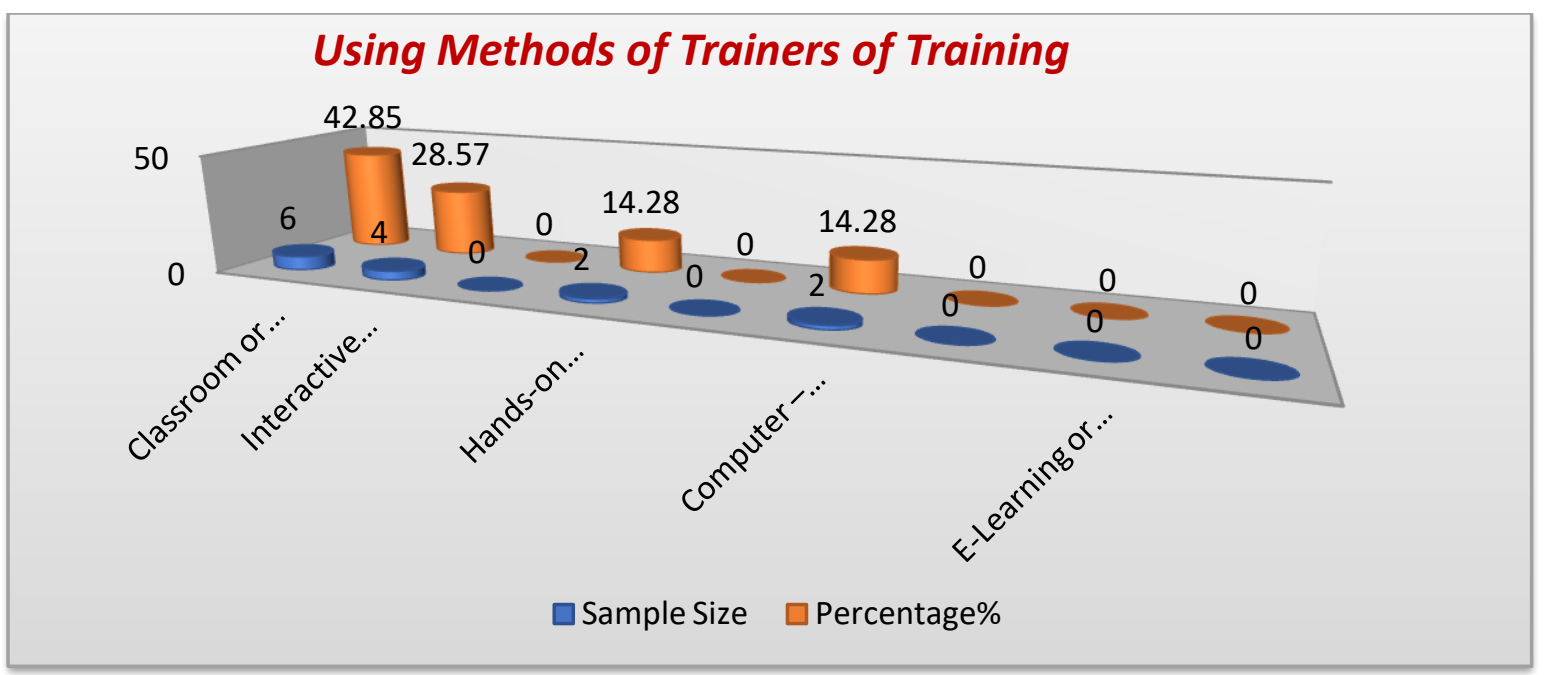

Figure 7. Methods of Trainers for Training

The figure above indicates the percentile analysis of the using methods and techniques of the trainers. Among the five types of using methods, $42.85 \%$ of trainers and 6 persons of the total sample size provide Classroom or Instructor-Led Training and $28.57 \%$ of them apply Interactive Training Techniques. E-Learning or Online-based Training Techniques are not used in this organizational training session.

4.7.3 Methods of Training to be Easier to Understand

Table 4. Methods of Training to be easier to understand of trainee

\begin{tabular}{lcc}
\hline Which methods do you think easier enough to understand the trainee? & Sample Size & Percentage\% \\
\hline Classroom or Instructor-Led Training & 07 & 50.00 \\
\hline Interactive Training Techniques & 05 & $35.7 \mathrm{I}$ \\
\hline Hands-on Training Techniques & $0 \mathrm{I}$ & $7 . \mathrm{I} 4$ \\
\hline Computer-Based Training Techniques & $0 \mathrm{I}$ & $7 . \mathrm{I}$ \\
\hline E-Learning or Online-based Training Techniques & 0 & 0 \\
\hline Total & $\mathrm{I}$ & $\mathrm{I}$ \\
\hline
\end{tabular}

Source: Field Survey, 2018

Under the opinion of the training providers, $50 \%$ of them feel very much comfortable using Classroom or InstructorLed Training Methods and any trainer does not use E-Learning or Online-based Training Techniques because of the lacking of knowledge and availability of modern technology facility. 35.71\% of the sample size replies that the Interactive Training Technique is easier to understand to the trainees.

\subsection{Measurement of Personal Experiences of the Employee}

The personal or individual experience of the employees is a vital issue for keeping a significant role in the organization. Considering this issue whole the sample size trained and non-trained were measured the service length in this organization.

Table 5. Length of Service of the Respondents

\begin{tabular}{lcc}
\hline Duration of service in the Organization & Sample size & Percentage\% \\
\hline I-2 Years & 24 & I7.I4 \\
\hline Less than 5 Years & 43 & $30.7 \mathrm{I}$ \\
\hline Less than I0 Years & $3 \mathrm{I}$ & 22.14 \\
\hline II- 20 Years & 42 & 30.00 \\
\hline
\end{tabular}

Source: Field Survey, 2018 
The above-mentioned table is the reflection of service length of I40 respondents. In this table, four types of service length have been considered. The employees who are less than five years stayed in this organization are demonstrated in this table and the belonging percentage is $30.7 \mathrm{I}$ and the second highest is $30 \% .24$ of the whole respondents are staying within I-2 years and their belonging percent is $17.14 \%$.

\subsection{Necessity of the Training}

Table 6. The opinion of the necessity of the training

\begin{tabular}{|c|c|c|}
\hline Do you think a training program is essential for a member of staff? & Sample size & Percentage $\%$ \\
\hline$\overline{Y e s}$ & II9 & 95.2 \\
\hline No & 06 & 4.8 \\
\hline Total & 125 & I00.0 \\
\hline
\end{tabular}

Source: Field Survey, 2018

To understand the necessity of training and development the above-mentioned question threw to the I25 among I40 respondents except for I5 trainers and the level of response 'Yes' is I I9 which implies $95.2 \%$ of whole respondents. And $4.8 \%$ replies 'No'. This number reflects that training is very necessary for most of the employees in a company.

\subsubsection{Understanding of Training}

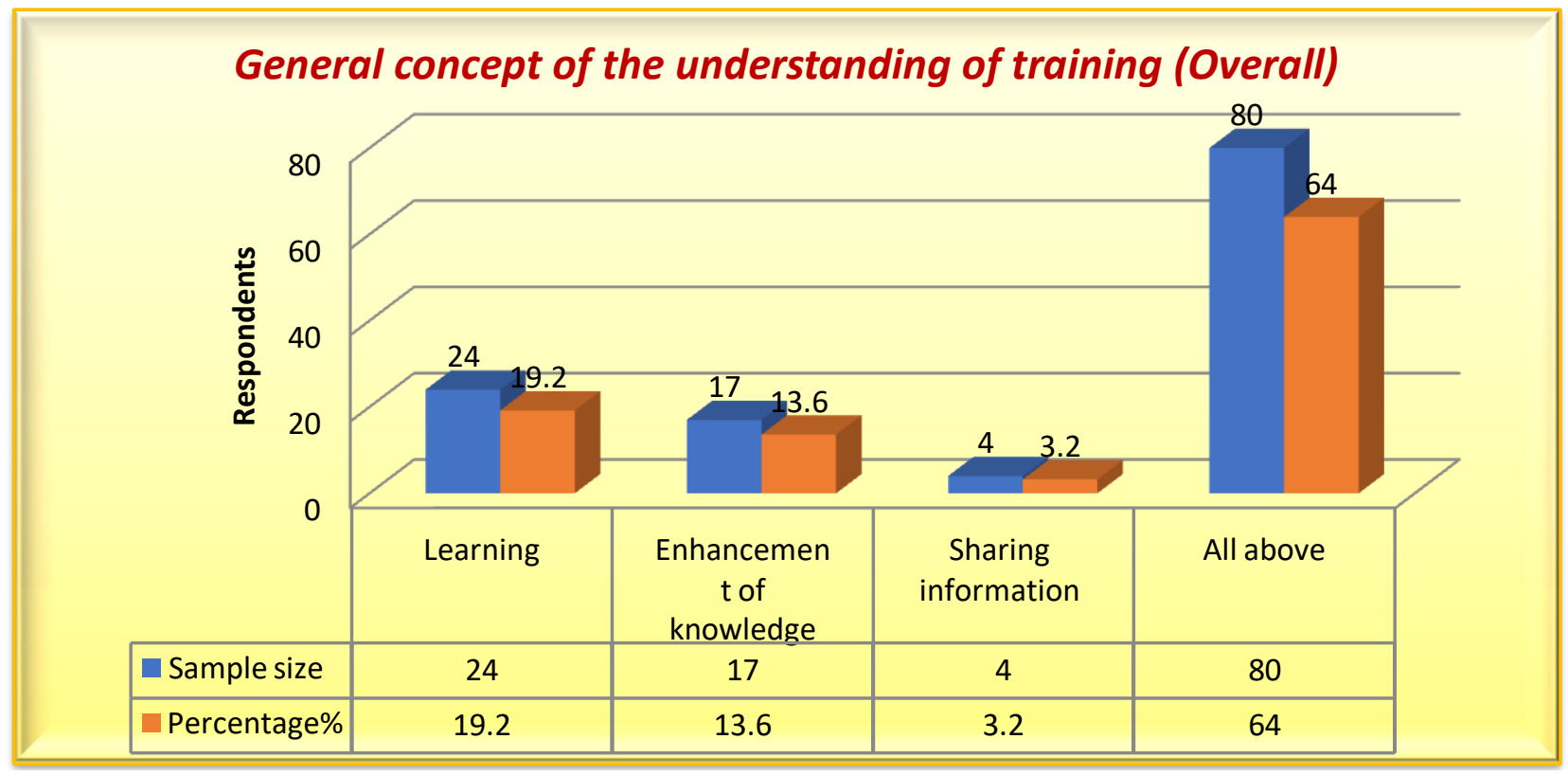

Figure 8. Understanding of training

Source: Field Survey, 2018

This part is furnished to justify the primary concept of understanding of training for all the trained and non-trained employees behind the training providers of the company. The majority of the respondents have given their opinion to all the above. All the above means the meaning of training is learning, enhancement of knowledge, and sharing information. $64 \%$ of all the respondents reply training means all the above.

\subsubsection{Provision of Formal Training}

Table 7 . The general concept of the provision of training organized

\begin{tabular}{lcc}
\hline Number of training program taken by you in this organization & Sample size & Percentage\% \\
\hline Once & 75 & I00 \\
\hline Twice & 50 & 66.66 \\
\hline More than two times & 25 & 33 \\
\hline
\end{tabular}

Source: Field Survey, 2018 
The main purpose to throw this question within the 75 persons who were trained with mid-level to top-level employees for understanding the opportunity to participate in providing training sessions of the Fareast Islami Life Insurance Company. This table refers that I00\% of employees have taken training by once $66.66 \%$ have got twice and $33 \%$ have taken more than two times in their service life. This scenario refers that the company is very concerned about providing training to the employees.

\subsubsection{Training Organized by the Company}

Table 8 . Length of training organized by the company

\begin{tabular}{|c|c|c|}
\hline Duration of the training program you have attended in your organization? & Sample size & Percentage \% \\
\hline I to 2 days & 38 & 49.5 \\
\hline 2 to 4 days & 22 & 29.7 \\
\hline 4 to 7 days & 15 & 19.8 \\
\hline Total & 75 & 100.0 \\
\hline
\end{tabular}

Source: Field Survey, 2018

To understand the duration of the training mainly prefers the company provides to the employees is the main objective in this part. The trend of this table refers that the company mainly prefers a I to 2 days training session. This table reflects that about $50 \%$ of training were provided within the duration of $\mathrm{I}$ to 2 days and 4 to 7 days is $19.8 \%$.

\subsection{Training Objectives}

Table 9. The general concept of the provision of training objectives

\begin{tabular}{|c|c|c|}
\hline Objectives of the training & Sample size & Percentage $\%$ \\
\hline To help improve performance & 20 & 26.66 \\
\hline To acquire more skill & 52 & 69.33 \\
\hline Improve customer relation & 03 & 4.00 \\
\hline Total & 75 & 100.0 \\
\hline
\end{tabular}

Source: Field Survey, 2018

Three types of indicators like to help improve performance; acquire more skill and improve customer relations were set for understanding the types of objectives got as an opportunity to take. By this questionnaire, about $70 \%$ of the respondents replied that it was 'To acquire more skill'. Only $4 \%$ of replies improve customer relations.

\subsection{Scope and Opportunity of Training \& Development}

This section is the reflection of understanding about the types of scope and opportunity which are created by training to the employees and unfold the opportunity to face future challenges and going development of the company.

Table I0. The primary concept of training and productivity performance

\begin{tabular}{|c|c|c|}
\hline Is training a must for enhancing productivity performance? & Sample size & Percentage $\%$ \\
\hline Fully agree & 54 & 72 \\
\hline Partially agree & $2 \mathrm{I}$ & 28 \\
\hline Disagree & 0 & 0 \\
\hline Unsure & 0 & 0 \\
\hline Total & 75 & 100.0 \\
\hline
\end{tabular}

Source: Field Survey, 2018

For enhancing the productivity performance of the employee is training needed for them by this statement majority of the respondents gave their answer 'Completely agree'. So, the range of completely agree is very high $72 \%$ among 75 respondents strongly agree and $28 \%$ of the respondents partially agree on that concern. The concerns on disagreeing and unsure imply $0 \%$ that is meant none can go against agreeing. Based on their opinion we can consider that training must enhance the productivity performance of the employees of a company. 


\subsubsection{Participation of Training}

Table II. Types of training they attend

\begin{tabular}{lcr}
\hline Type of training you participate & Sample size & Percentage (\%) \\
\hline Refresher training & 0 & 0 \\
\hline Orientation training & 07 & 9.3 \\
\hline Profession or Development training & 14 & 18.66 \\
\hline Communication Skill Training & 47 & 62.66 \\
\hline Relationship Management Training & 07 & 9.3 \\
\hline \multicolumn{1}{r}{ Total } & 75 & 100.0 \\
\hline
\end{tabular}

Source: Field Survey, 2018

\section{Types of training they attend}
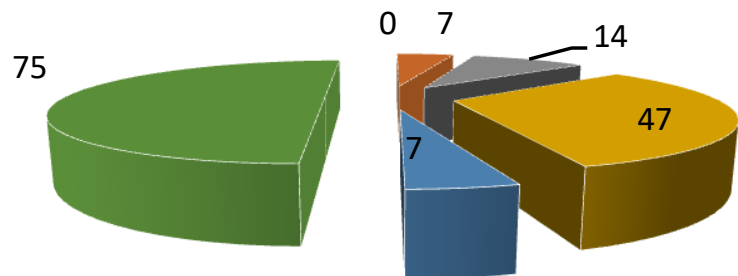

Figure 9. Types of training they attend

The company provides different types of training programs for the development of the quality and strength of its employees. Providing remarkable training are Refresher training, Orientation training, Career or Development Training, Communication Skills Training, Relationship Management Training, etc. As per the study conducted on the types of training, the employees attended in their service period. Among 47 of the whole 75 respondents took part in Communication Skill Training and hold $62.66 \%$ of the whole. Belonging second highest position is Career or Development training and the equal position is staying Orientation training and Relationship Management Training and symbolize 9.3\% in parallel.

\section{I0 Key Skill for the Future}

Development for the future means the sustainable development of a company depends on the skill development of employees. Because, the performance, productivity, and services by the employees are closely related to their skill development. Fareast Islami Life Insurance provides different types of skill development training to its employees. Measuring the skills and competency of employees are considered in this part.

\section{I0.I Type of Skills Improved by Training}

\section{Type of skills improved by training}

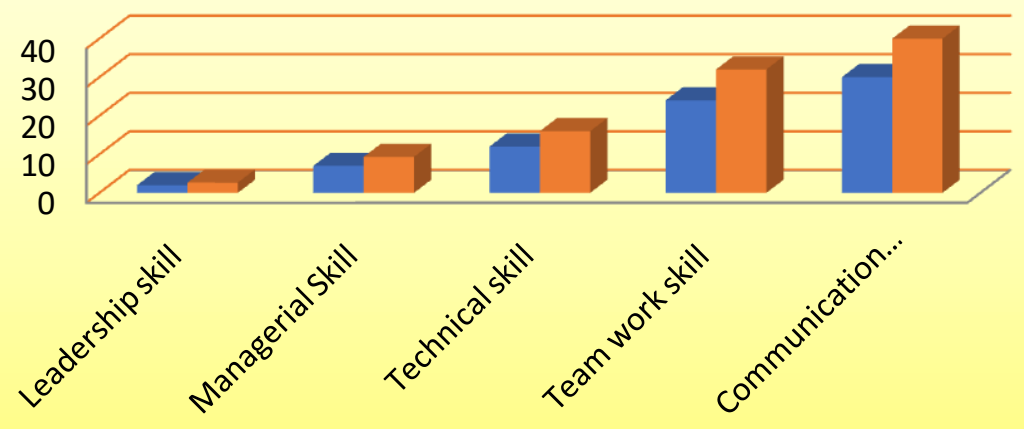

Sample size

Percentage\%

Figure I0. Skills Improved by training

Source: Field Survey, 2018 
For the evaluation of the competency level of the trained employees, this part of the study was conducted. Five types of skilled performance like Leadership skill, Managerial Skill, Technical skill, Teamwork skill, and Communication skills have been considered for the measurement of the employee's competency level. As per the study conducted that the employees said the communication skill is improving $40 \%$. It can interpret that the most of the employees said that the training program help to improve their leadership skill its $2.66 \%$, managerial skill $9.33 \%$ and technical skill is $16 \%$, teamwork skill is $32 \%$. So it is shown that the training program is more effectively adapted to the employees.

\section{II Measurement of Confidence Level}

To measure the confidence level of the employees in Fareast Islami Life Insurance Company two steps measurement policy had been taken into consideration for them one was before training measurement and another one is after training measurement. The following tables and figures are the reflection of that.

\section{II.I Confidence Level Measurement before Training}

Table 12. Confidence Level measurement before training

\begin{tabular}{|c|c|c|c|c|c|}
\hline Before training & $\begin{array}{l}\text { Strongly disagree } \\
(\%)\end{array}$ & $\begin{array}{l}\text { Disagree ( } \\
\%)\end{array}$ & $\begin{array}{l}\text { Neutral } \\
(\%)\end{array}$ & Agree (\%) & $\begin{array}{l}\text { Strongly } \\
\text { agree }(\%)\end{array}$ \\
\hline It was difficult for you to work effectively & 0 & 9.0 & 45.33 & 36.00 & 9.3 \\
\hline $\begin{array}{l}\text { You were less confident and not having } \\
\text { proper knowledge }\end{array}$ & 0 & 0 & 26.66 & 54.66 & I8.66 \\
\hline You were mostly dependent on your senior & 0 & 0 & 9.3 & 81.33 & 9.3 \\
\hline You were disgruntled with your job & 0 & 0 & 9.3 & 81.33 & 9.3 \\
\hline
\end{tabular}

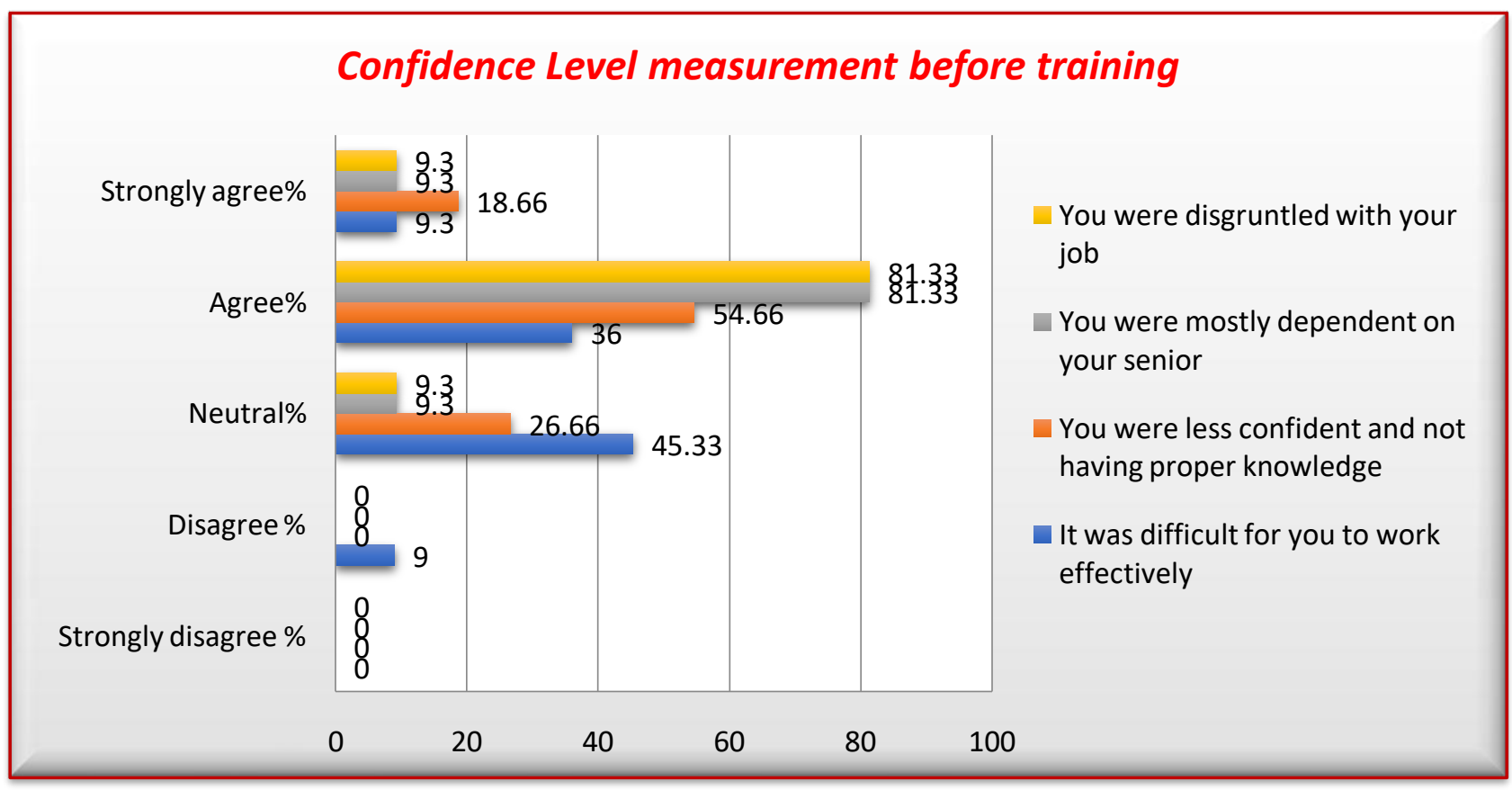

Figure I I. Confidence Level before training Source: Field Survey, 2018

The confidence level of the employees has been measured by using two tires. Before participating in the training program and on the other hand in participating after the program. Because of comparing within two tires, we can able to understand their confidence level. In the above figure, four indicators have been used to measure their confidence level before training. And to know their opinion five types of indicators have been used. Most of the indicators against measuring their confidence level are very low by concerning with their $82 \%$ opinion is agree to their performance level. $45.33 \%$ were neutral against the indicators of "It was difficult for you to work effectively" and 36.00\% agreed with them and $9.3 \%$ kept their opinion strongly agree. 


\section{I I.2 Confidence Level after Training}

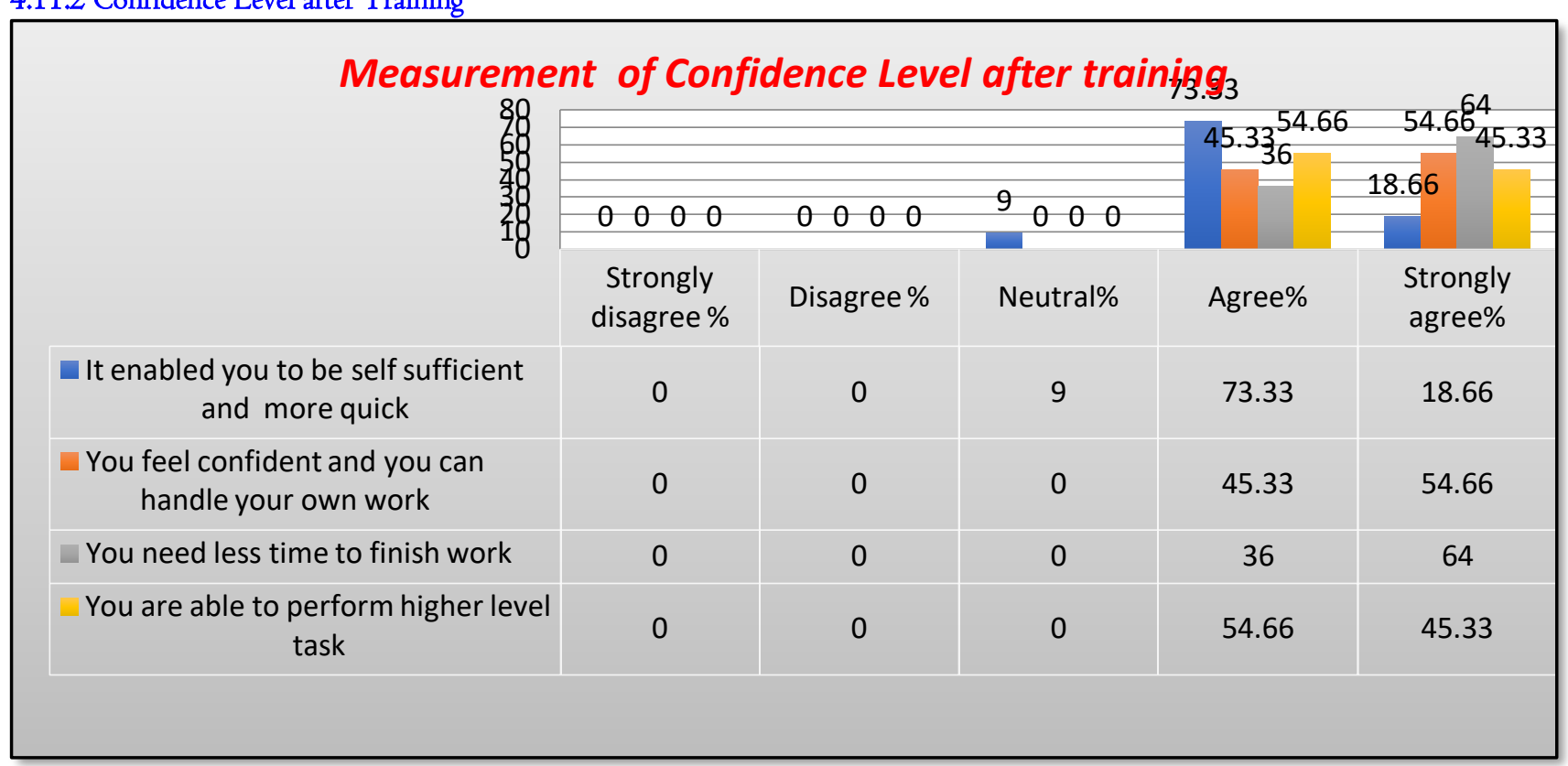

Figure 12. Confidence Level after training

Source: Field Survey, 2018

The figure above shows the measurement of confidence level after receiving training. And the major portion of the questions related to their ability to do work, taking time to provide service, the capability to perform the task, and building their skill are reflected in their result towards the indicators of agreeing and strongly agree. Against the question first $73.33 \%$ of the respondents replied agree, $18.66 \%$ replied strongly agree and $9 \%$ of them were neutral. And against the third, fourth $\&$ fifth questions the level of opinion to agree $45.33 \%, 36 \% \& 54.66 \%$ respectively. On the other hand opinion towards strongly are $54.66 \%, 64 \% \& 45.33 \%$ respectively. So, the result of this part shows that after participating in the training session most of the respondents feel confident with their performance.

\section{I2 Measurement of the Satisfactory Level of the Employee}

The purpose of this part of the study is to measure the satisfaction level of the trained employees of 75 persons of the respondents. The effectiveness of the training program, quality of provided training program, subject knowledge of the trainers, and the relevancy of their job are the considering issues of this part.

\section{I2.I Satisfactory level of the Effectiveness of Training}

Table I3. Satisfactory level of the effectiveness of the training program

\begin{tabular}{|c|c|c|}
\hline Are you satisfied with the effectiveness of the training program? & Sample Size & Percentage $\%$ \\
\hline Excellent & 20 & 26.66 \\
\hline Very good & 34 & 45.33 \\
\hline Good & I4 & 18.66 \\
\hline Average & 07 & 9.33 \\
\hline Poor & 0 & 0 \\
\hline Total & 75 & 100.0 \\
\hline
\end{tabular}

Source: Field Survey, 2018

The test of a satisfactory level of the effectiveness of the training program had been conducted by applying four indicators. And the trend of their response to the indicator "Very good". 45.33\% of the respondents replied very well, $26.66 \%$ replied excellently, $18.66 \%$ replied good and $9.33 \%$ replied average. As a result, we can agree with them that they were satisfied participating in the training program. 


\subsubsection{Satisfactory Level Measuring on the Quality of Training Program}

TableI4. Satisfactory level to the quality of training program

\begin{tabular}{|c|c|c|}
\hline Are you satisfied with the quality of the training program? & Sample Size & Percentage $\%$ \\
\hline Excellent & 10 & 13.23 \\
\hline Very good & 30 & 40.26 \\
\hline Good & 27 & 35.74 \\
\hline Average & 28 & 10.77 \\
\hline Poor & 0 & 0 \\
\hline Total & 75 & 100.0 \\
\hline
\end{tabular}

Source: Field Survey, 2018

By conducting to measure the satisfaction level of the trained employees most of them were satisfied against the question here. $40.26 \%$ of them are staying in the indicators very good, $35.74 \%$ are in good, $13.23 \%$ are in excellent, $10.77 \%$ are on average and $0 \%$ are staying in poor. So, it is proved that they are not staying below the level of satisfaction against the quality of the training.

4.I2.3 Measurement of Satisfactory Level on Trainer's Subject Knowledge

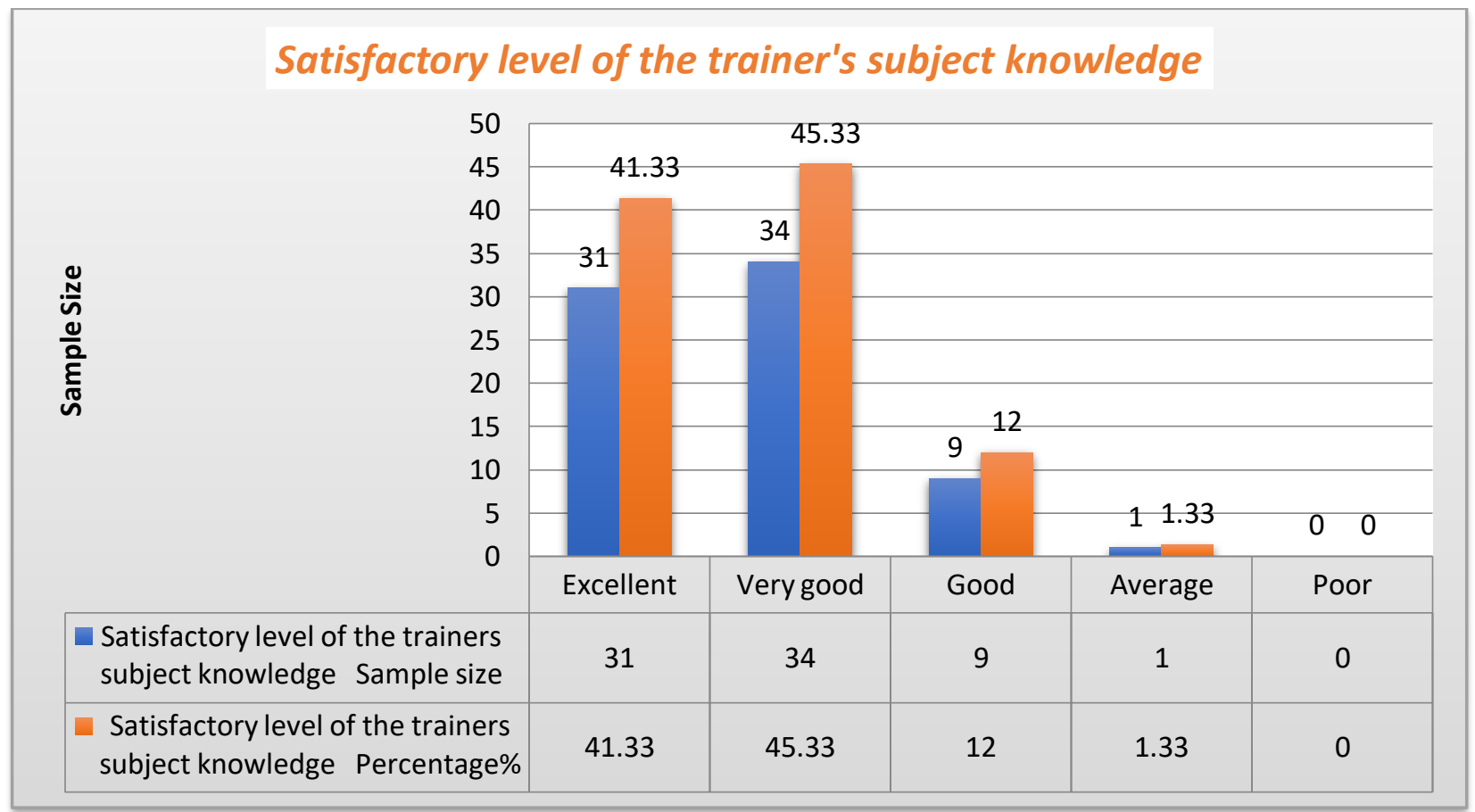

Figure I3.Trainer's subject knowledge Measurement Source: Field Survey 2018

In the part of the measurement of a satisfactory level of the trained employees against their training providers' subject knowledge, most of the respondents are staying in the indicator very good. And belonging percentile against the indicator excellent is $41.33 \%$, very good is $45.33 \%$, good is $12 \%$ and the average is $1.33 \%$. None can find against the poor. So, most of the respondents were satisfied with the subject knowledge of the training providers. 


\section{I2.4 Measurement of Satisfactory Level after Training}

Table I5. Satisfactory Level measurement after training

\begin{tabular}{lcccccc}
\hline Opinion & $\begin{array}{l}\text { Strongly disagree } \\
(\%)\end{array}$ & $\begin{array}{l}\text { Disagree } \\
(\%)\end{array}$ & $\begin{array}{l}\text { Neutral } \\
(\%)\end{array}$ & $\begin{array}{c}\text { Agree (\%) } \\
\text { Strongly agree } \\
(\%)\end{array}$ \\
\hline $\begin{array}{l}\text { The training and development system in } \\
\text { FILICL is superior }\end{array}$ & 0 & 0 & 0 & 64 & 36 \\
\hline $\begin{array}{l}\text { Enough practice was given during training } \\
\text { session }\end{array}$ & 0 & 0 & 0 & 81.33 & 18.67 \\
\hline $\begin{array}{l}\text { Training duration is sufficient for getting } \\
\text { appropriate knowledge }\end{array}$ & 0 & 0 & 0 & 80.10 & 19.90 \\
\hline Average & 0 & 0 & 0 & $75.14 \%$ & $24.86 \%$ \\
\hline
\end{tabular}

Source: Field Survey, 2018

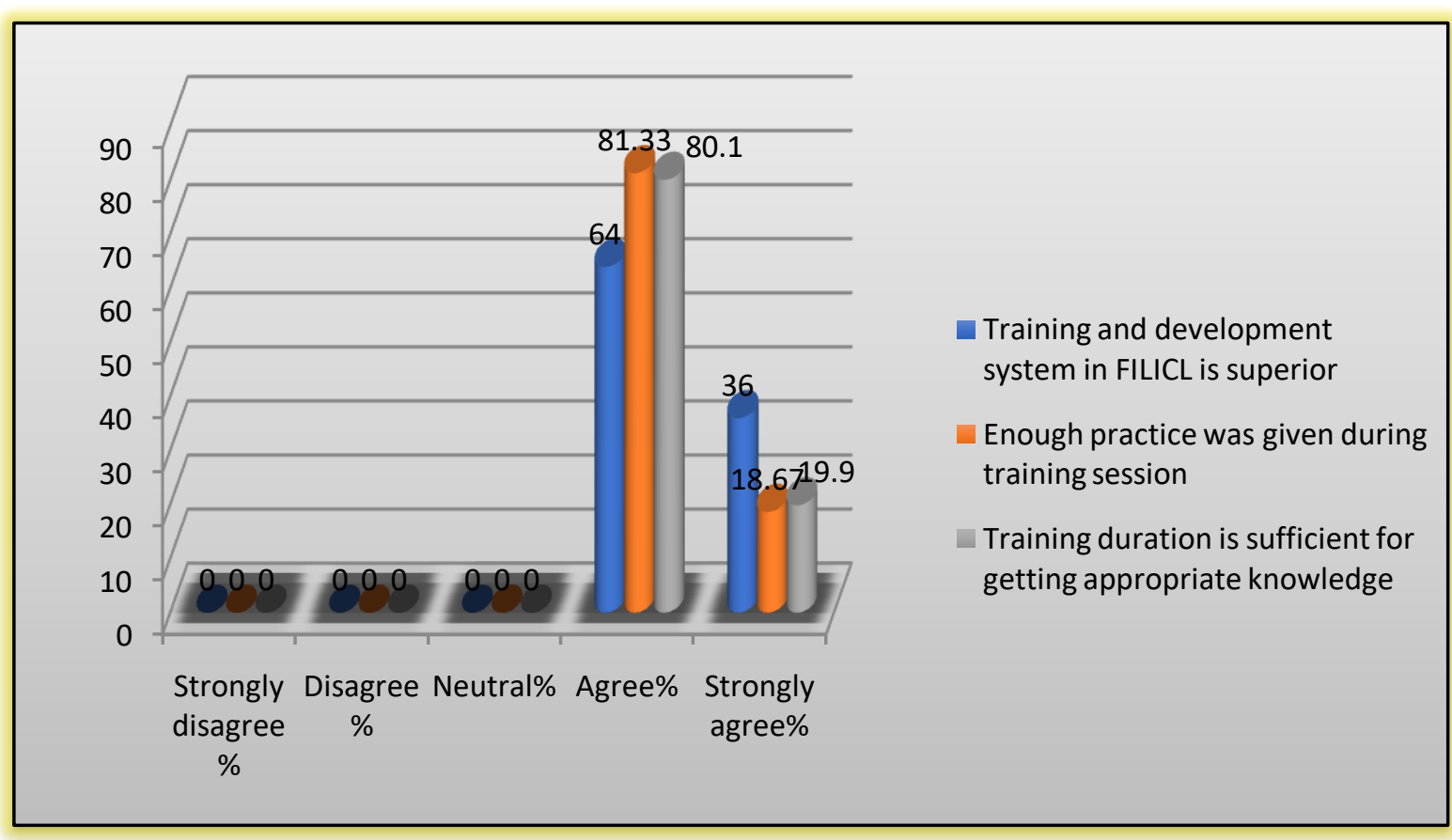

Figure I4. Measurement of satisfaction after training

In the figure above discourses that the satisfactory level of the trained employees is very high against the provided training program by Fareast Islami Life Insurance. Four types of opinions were collected from the 75 trained employees against three questionnaires. Most of them kept their opinion against in between agree and strongly agree. And their percentile average is $75.14 \%$ against agree and $24.86 \%$ against strongly agree. So, the overall measurement of their satisfactory level of providing training conducted by FILIC is satisfied.

\subsection{Measuring Training Benefits of the Company}

Arranging a training program to the employees is considered an investment for the present and long-run benefit for the future. And the benefits of the company may visual (Increase of premium, an increase of investment, increase of assets, etc.) on the one hand and non-visual (Change of behavior, improve performance, knowledge, and productivity of the employees, etc.) on the other hand. All the benefits comprise the development of that company. Fareast Islami Life Insurance Company arranges different types of training programs for its employees regularly. The purpose of these training programs to the employees is to enhance performance, increase knowledge, change behavior to the clients, and keep fit for the productivity of the company. This company measures non-visual benefits by applying performance appraisals, productivity tests, behavioral tests, and knowledge measurement matrix to their employees. And the visual benefits of the company have been shown with the help of comparison on a yearly increase of different issues. Five years of data (2013-2017) have been shown in comparison. 
4.I3.I Yearly Comparison of Gross Premium

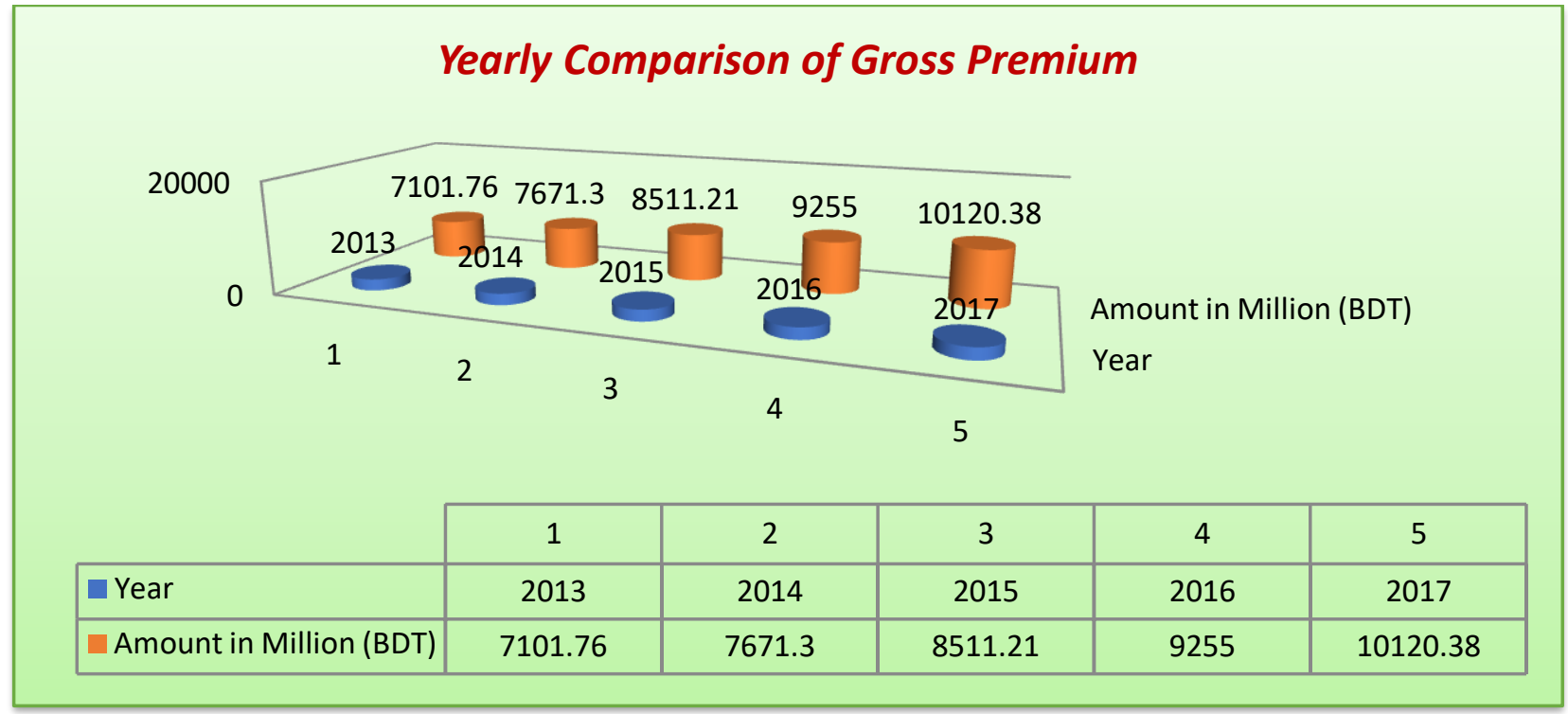

Figure I5. Comparison of Gross Premium

Source: FILIC Annual Report, 2017

In the table and figure above reflects has been shown year-wise gross premium of the company. The immediate past five years of data (2013-2017) have been shown in consideration. The nature of the shown data indicates that the gross premium of the company gradually increases year by year. So, the amount of the gross premium was BDT 7IOI.76 in the year of 2013, and in the year of 2017, it had reached BDT I0I20.38.

4.I3.2 Yearly Paid Up Capital Scenario of the Company

Table 16. Total Paid Up Capital

\begin{tabular}{cc}
\hline Year & Amount in Million (BDT) \\
\hline 2013 & 566.23 \\
\hline 2014 & 566.23 \\
\hline 2015 & 622.86 \\
\hline 2016 & 622.86 \\
\hline 2017 & 747.43 \\
\hline
\end{tabular}

Source: FILIC Annual Report, 2017

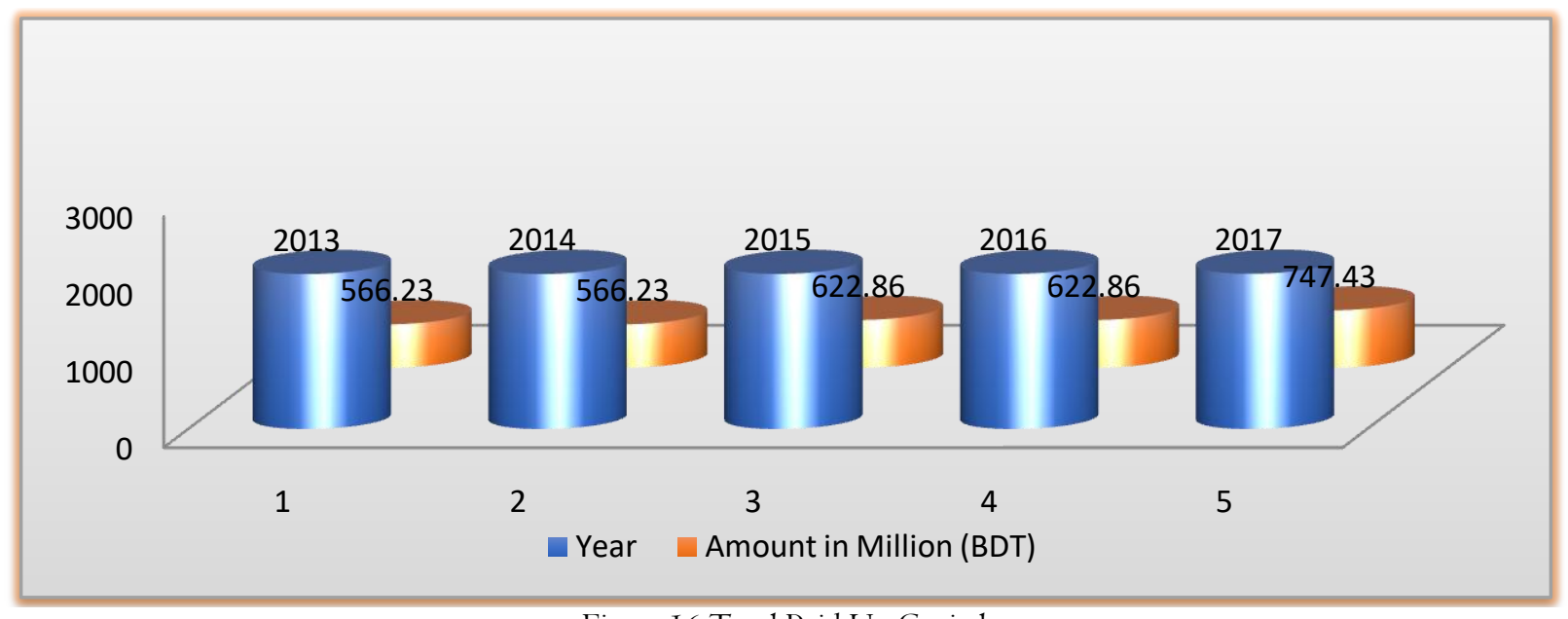

Figure I6.Total Paid Up Capital 
The table and figure above is the comparison of the total paid-up the capital ratio of the company from the year of 20I3-2017. The Total Paid Up Capital amount of the company was 566.23 million BDT in 2013 and in 2017 it had been reached in 747.43million BDT. It has been increased from 2013 to 2017 in BDT I8I.2 million and a rate of increase of $32 \%$.

\section{I3.3Year Wise Assets of the Company}

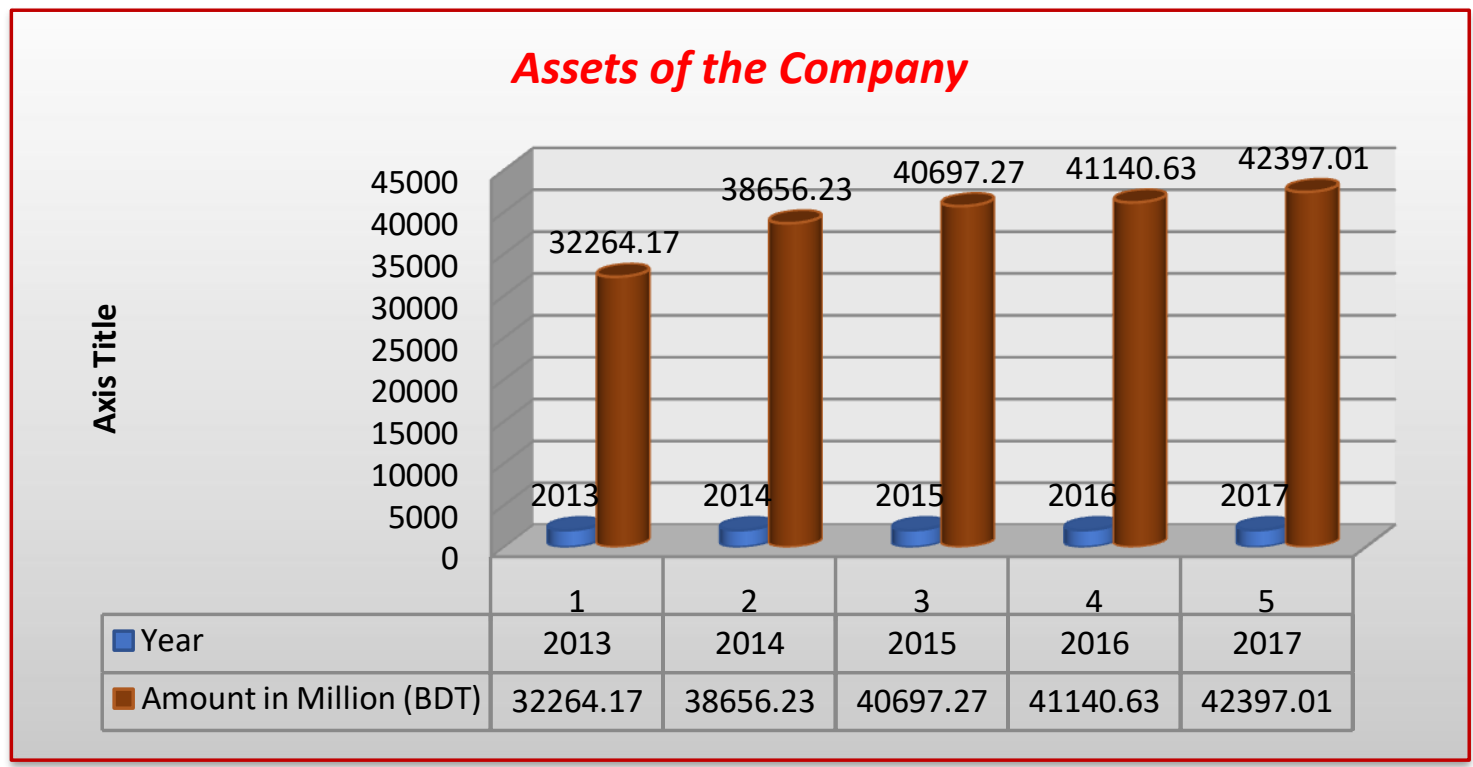

Figure 17. Assets of the Company

Source: FILIC Annual Report, 2017

The table and figure above is the comparison of total asset ratio of the company from the year of 2013-2017. The Total asset amount of the company was 32264.I7million BDT in 2013 and in 2017 it had been reached in 42397.0Imillion BDT. It has been increased from 2013 to 2017 in BDT I0I32.84 million and the rate of increase 3I.4\%.

\section{Major Problems Faced During Training Period}

- Lack of information;

- Lack of a suitable training environment;

- Lack of capable trainer;

- Lack of appropriate training instruments;

- Lack of flexibility

\section{I Suggestions on how to Solve the Arising Problems}

- Training must be informative;

- The environment must be quiet;

- Involving capable trainers;

- Adding proper training instruments

\subsection{Findings}

- It is found that $95.2 \%$ of the respondents replied that it is very required to arrange a training program for improving the individual skill and progress of its business.

- It is showing by the study that $62.66 \%$ of respondents attended only one training program.

- It is found that $42.85 \%$ of the respondents opined that the trainers followed Classroom or Instructor-Led Training and $28.57 \%$ of them applied Interactive Training Techniques.

- The study exposed that more than $50 \%$ of the respondents explained about the duration of the training program where the joined was I - 2 days and $19.8 \%$ received $4-7$ days training. 
- $40 \%$ of the respondents said that the training program may help to improve their teamwork skills and $32 \%$ said technical and other skills.

- It is found that $86.66 \%$ of the respondents explained that the trainer was experienced in the session and some of the respondents said they do not get correct information.

- It is found $30 \%$ of the respondents said the trainer is well prepared for the training program.

- It is found that $40 \%$ of the respondents said the communication skill improved, $16 \%$ said their technical skill improved and another $32 \%$ said their teamwork skill improved.

\subsection{Recommendations}

- To fill the gap of the workforce and organizations should arrange further advanced training programs to the employees who are less experienced than others.

- The duration of the training program should be augmented especially to the inexperienced and the fresher because of helping to learn in detail, update their knowledge, and enhance working ability.

- It also recommended having outside experts for conducting training to the employees which will be attracted and make them serious about training.

- It is also recommended that to permit employees for asking questions during a training session which may help them to clarify their doubts and queries.

- Feedback should be taken after the ending session from the participating candidates about training for helping the organization to arrange some training more effectively for the future.

\section{Conclusion}

Man is the decisive capital of any organization because the success or failure of any organization depends on the competence and efficiency of manpower and their performance. The complete-scale of activities of an organization revolves around human resources. Therefore, people are the most significant resources of any organization. Employee development is carried through the programs of training. Training brings the necessary improvement towards the human resources working at different levels. From the study, it can execute that a company is provided that training to workers effectively but still it can make it more effective by escalating the length of the training program and a fascinating expert from outsiders to guide employees. This will be helped to make employees more solemn to training. Flexibility should be given to the employees for helping them to raise voice and eagerness to ask questions to the trainer. The training program helps to increase the knowledge, skill, and ability of the workforce of a company. During organizing the training session, candidates should be selected as per need basis because of providing an opportunity for every employee who really in need of training. In this way, both organizations and employees will be benefited. In this study reflect that $32 \%$ of paid-up capital and $31.4 \%$. Of total assets are increased gradually within the year of 2013 and 20I7. By conducting training programs under the policy, this company is going to achieve its goals and has become one of the best insurance companies in Bangladesh.

\section{References}

Ali, M. M. (2000). Provision of microinsurance for microfinance clients. Microfinance Newsletter, 7(I), 2-5.

Amadi, E. J. (2014). The Effect of Training and Development on Employees' Performance; At Safaricom Limited Call Centre. Retrieved

http:/ erepository.uonbiac.ke/bitstream/handle/II295/78203/Amandi_The\%20effect\%20of\%20training\%20a nd\%20development $\% 20$ on $\% 20$ eployee $\% 27$ s.pdt?sequence $=48$ is Allowed $=y$

Ahmad, E., \& Malik, A. (2009) Financial Sector Development and Economic Growth: an Empirical Analysis of Developing Counties. J Eco Co-operate Develop 30(I), I7-40.

Allen, M. (2010). Corporate universities 2010: globalization and greater sophistication. The Journal of International Management Studies, 5(I), 48-50.

Bangladesh Insurance Association. (2016). Retrieved from http://www.bia.gov.bd/aboutbia/objective.html.

Chaudhrui, A. H. (2008). Risk and Insurance. Brothers Publication, Dhaka.

Chowdhury, S.E. (20I4). Financial System in Bangladesh. Retrieved from http://www.scribd. com/doc/29065718/Financial-System-in-Bangladesh.

Ferdawshi, J. A. (20I6). Training \& development of M\&J Group.

Garner, E. (2012). Training skills: How to improve the skills and performance of your employees. Ventus: Eric Garner \& Ventus Publishing ApS. Available at: http://www.bookboon.com /

Greenhause, J. H., Callanan, G. A., \& Godshalk, V. M. (2000). Career Management (3rd ed.). Pennsylvania, USA: Dryden Press. 
Imran, M., \& Tanveer, A. (2015). Impact of training \& development on employees' performance in banks of Pakistan. European journal of training and development studies, 3(I), 22-44.

Insurance Development \& Regulatory Authority Bangladesh. (2013). Retrieved from http://www.idra.org.bd/idraorg/index.htm

Islam, K. M. A., \& Zaman, M. (2013). Job satisfaction \& bankers' turnover: a case study on Bangladesh commerce bank limited. International Journal of Business and Management Review, I(4), I-I4. Retrieved from https://www.eajournals.org/journals/international-journal-of-business-and-management-review-ijbmr/vol-I-issue-

Khan, I., Rahman, N. N. B. A., Yusoff, M. Y. Z. B. M., \& Nor, M. R. B. M. (2016). History, problems, and prospects of Islamic insurance (Takaful) in Bangladesh. SpringerPlus, 5(I), I-7.

Khan, A. M. B. (2014). Directorate of Distance Education: Training and Development, Pondicherry University, India. I-I I2.

Kumpikaite, V., \& Sakalas, A. (20II). The model of human resource development system's evaluation. International Conference on E-business, Management and Economics (pp. 46-50). Singapore: IACSIT Press.

Khan, R. A. G., Khan, F. A., \& Khan, M. A. (20II). Impact of training and development on organizational performance. Global journal of management and business research, $I I(7)$.

Mwita, J. I. (2000). Performance management model: A system-based approach to system quality. The International Journal of Public Sector Management, I3 (I), 19-37.

Noe, R. A. (2008). Employee training \& development. New York: MacGraw-Hill, Inc.

Qayyum, A., Sharif, M. T., Ahmad, A., Khan, M. S., \& Rehman, K. -u. (2012). Training \& development practices in National Bank of Pakistan. Information Management and Business Review , 8-I7.

Ramakrishna, G., Kumar, K., Girdhar, M., \& Krishnudu, C. H. (2012). Effectiveness of Training and Development Programmes-A Case Study of Canara Bank Employees in Kurnool District. International Journal of Multidisciplinary Research, 2(4), I50-I62.

Rahman, M. A. (2013). Comparative study on the efficiency of Bangladeshi conventional and Islamic life insurance industry: a non-parametric approach. Asian Business Review, 2(3), 88-99.

Raja, D. V. A. J., \& Kumar, R. A. R. (2016). A Study on Effectiveness of Training and Development in Ashok Leyland all over India. Journal of Management, 3(I).

Rispler-Chaim, V. (I99I). Insurance and semi-insurance transactions in Islamic history until the I9th century. Journal of the Economic and Social History of the Orient, 34(2), I42-158.

Sarwar, M. J. (2016). Future challenge in Islamic insurance (takaful) in Bangladesh. Aust J Sustainable Business Society, 2(I), 69-80.

Sharma, T., \& KU, K. (2013). Training Process-An Overview; Role, Responsibilities and Challenges to Training Manager. Lecture Materials for Training and Development Course in the Deaprtment of Commerce.

Samarth, R. D. (2003). Transformation of Indian Insurance Industry in the $2 \mathrm{I}^{\text {st }}$ Century. Key Note Address at the FortyEighth Annual Conference, Kolkata, 7 September

Spender, J. C. (2002). Knowledge management, uncertainty, and an emergent theory of the firm. The strategic management of intellectual capital and organizational knowledge, I49-I62.

Vyas, B., \& Mistry, C. K. (2015). A study on Effectiveness of Training and Development in Cement Industry. System, I, I-0.

\section{Appendix}

This questionnaire has been designed to implore information for merely scholastic rationale. This is to facilitate the researcher, accomplishing of his research scheme on the objectives of the topic; "The effect of training and development on employee performance - A study on Fareast Islamic Life Insurance Company Limited” in pursuance of CEMBA degree of Open University.

\section{SECTION A: BASIC DEMOGRAPHIC DATA}

\begin{tabular}{l}
\hline Name of the Respondent: \\
\hline Name of the Organization: \\
\hline Designation: \\
\hline Length of service: (Total): \\
\hline Length of service: (This Organization): \\
\hline
\end{tabular}


(PLEASE TICK WHERE APPROPRIATE)

I. Age? (Years)
a) $18-25($ ( )
b) $26-35()$
c) $36-45($ ( )
d) $46-55$ ( )
e) $56-59($

2. Gender
a) Male ( )
b) Female ( )

3. Educational Background
a) Primary School ( )
b) High School ( )
c) Diploma Level ( )
d) Degree ( )
e) Honors $($ )
f) Masters Degree ( )
g) Others (please specify) ( )

4. How long have you been working with FILICL?
a) I-2 Years $($ )
b) Less than 5 Years ( )
c) less than 10 Years ()
d) II -20 Years ( )

\section{SECTION B: MEASURING GENERAL CONCEPT OF TRAINING \& DEVELOPMENT}

I. What do you understand by training?
a) Learning ( )
b) Enhancement ( )
c) Sharing information ( )
d) All the above ( )

2. Is training a must for enhancing efficiency performance?
a) Completely agree ( )
b) Partially agree ( )
c) Disagree ( )
d) Unsure ( )

3. Dou you feel the training program is obligatory for the staff?

a) Yes ( )

b) No ( )

4. Your opinion about the enhancement of knowledge after the training program?
a) Yes ( )
b) No ( )

5. Whether training applies to the needs of the institute?

a) $\operatorname{Yes}()$

b) No ( )

\section{SECTION C: MEASURING GENERAL CONCEPT OF NON TRAINED EMPLOYEE}

I. Did you attend the training program before induction in the organization?

a) $\operatorname{Yes}()$

b) No( )

2. Are you motivated by and satisfied with the training program of FILICL
a) $\operatorname{Yes}($ )
b) $\mathrm{No}($ )

3. Has training offered you the opportunity to identify any potential you have for further development?

a) $\operatorname{Yes}($ )

b) No( )

4. In your opinion, do you think training has helped improve your performance in FILICL? 
a) $\operatorname{Yes}($ )

\section{SECTION D: MEASURING GENERAL CONCEPT OF TRAINED EMPLOYEE}

I. Have you had any form of training since you joined FILICL?

a) $\operatorname{Yes}($ )

2. What were the objectives of the training ?

a) To help improve performance ( )

b) To acquire more skills ( )

c) Improve customer relation ( )

3. What kind of training did you participate in?

a) Refresher Training ( )

b) Orientation Training ( )

c) Career or Development Training ( )

d) Job Training ( )

e) Other(please specify) ( )

4. In your opinion, do you think training policy and procedures at FILICL are ?

a) planned and systematic ( )

b) Unplanned and unsystematic ( )

c) Not sure ( )

5. If No, Explain Why?

\section{SECTION E: TRAINING EVALUATION}

I. Do you identify how the training was evaluated?

a) $\operatorname{Yes}($ )
b) $\operatorname{No}()$

If yes, please specify?

2. Which type of training program had you undergone from the following?

a) Internal ( )

b) External ( )

c) Both ( )

3. Do you satisfy with the usefulness of training program?
a) Excellent ( )
b) Very Good ( )
c) Average ( )
d) $\quad$ Poor ( )

4. Dou you think that the feedback can evaluate the success of training program?
a) Yes ( )
b) $\quad$ No ( )

5. What should be ideal time to evaluate training?
a) Immediate after training ( )
b) After I5 days ( )
c) After I months ( )
d) Can't say ( )

6. Is the whole feedback after training worth the time, money, effort?
a) Yes ( )
b) $\quad$ No ( )
c) Can't say ( )

7. Do you like to be present at the training course?
a) $\quad$ Yes $($ )
b) $\quad$ No $($ ) 
8. Write 2 (Two) problems faced by the organization regarding training program.

a).

b).

9. Write 2 (Two) suggestions to solve the problems.

a).

b).

SECTION F : MEASUREING SATISFACTORY LEVEL OF TRAINED EMPLOYEE

$\mathrm{I}=$ Strongly disagree, 2 = Disagree, 3 = Neutral, $4=$ Agree, $5=$ Strongly agree

\begin{tabular}{|c|c|c|c|c|c|c|}
\hline Sl. No & Skill Items & $\begin{array}{l}\text { Strongly } \\
\text { disagree }\end{array}$ & Disagree & Neutral & Agree & $\begin{array}{l}\text { Strongly } \\
\text { agree }\end{array}$ \\
\hline OI. & $\begin{array}{l}\text { Human resources get the chance to discuss training and } \\
\text { development requirements with their seniors. }\end{array}$ & & & & & \\
\hline 02. & $\begin{array}{l}\text { FILIC has given training opportunities to the employees } \\
\text { with enabling to enlarge your range of skills and abilities. }\end{array}$ & & & & & \\
\hline 03. & Training and development system in FILIC is superior. & & & & & \\
\hline 04. & $\begin{array}{l}\text { Enough practice is given during training session and } \\
\text { training duration is sufficient for getting appropriate } \\
\text { knowledge. }\end{array}$ & & & & & \\
\hline 05. & $\begin{array}{l}\text { You are contented with the method of training and the } \\
\text { trainers. }\end{array}$ & & & & & \\
\hline 06. & $\begin{array}{l}\text { You learned the technical skills through training } \\
\text { program and have good impact over your technical hand. }\end{array}$ & & & & & \\
\hline 07. & $\begin{array}{l}\text { Employees learned the behavioral skills through training } \\
\text { program and using learnt behavioral skills on job. }\end{array}$ & & & & & \\
\hline 08. & $\begin{array}{l}\text { Before training it was difficult for you to work } \\
\text { effectively. }\end{array}$ & & & & & \\
\hline 09. & $\begin{array}{l}\text { Before training you were less confident and not having } \\
\text { proper knowledge. }\end{array}$ & & & & & \\
\hline IO. & $\begin{array}{l}\text { Before training you were disgruntled with your job and } \\
\text { mostly dependent on your senior staff. }\end{array}$ & & & & & \\
\hline II. & Training enabled you to be self sufficient more quickly. & & & & & \\
\hline I2. & $\begin{array}{l}\text { After training you feel confident and you can handle } \\
\text { your own work. }\end{array}$ & & & & & \\
\hline I3. & After training you need less time to finish your work. & & & & & \\
\hline I4. & After training you are able to perform higher level task. & & & & & \\
\hline I5. & $\begin{array}{l}\text { You liked the training program conducted in this } \\
\text { organization. }\end{array}$ & & & & & \\
\hline
\end{tabular}

\section{SECTION G: - SCHEDULED INTERVIEW QUESTIONS FOR STAFF TRAINING PROVIDER OF FILICL.}

I. Did FILICL provide training for development employees over the past 5 years?

2. How long has FILICL been given this type of training for the development of its own?

3. Write your expression on the major purposes of training.

4. What are the internal and external factors that affect of training do you think?

5. Has FILICL training policy documented?

6. Please briefly describe the training policy and procedures in FILICL? 
7. Are the employees of FILICL aware of the training policy?

8. How can training develop in FILICL practice?

9. What type of values applies by the training at the workplace?

I0. On the training process.

a) How are individual and organizational needs determined?

b) How are staffs selected for training?

II. Dou you keep personal profile of each employee?

I2. Do you keep records on training on each employee?

13. Do you have career progression projections for each employee?

I4. Do you have training and development projections for each employee?

\section{Copyrights}

Copyright for this article is retained by the author(s), with first publication rights granted to the journal. This is an open-access article distributed under the terms and conditions of the Creative Commons Attribution license (http://creativecommons.org/licenses/by/4.0/). 